\title{
(11) Nordregio
}

\section{THE COMPACT CITY OF THE NORTH}

- functions, challenges and planning strategies

Moa Tunström, Johannes Lidmo \& Ágúst Bogason

NORDREGIO REPORT 2018:4

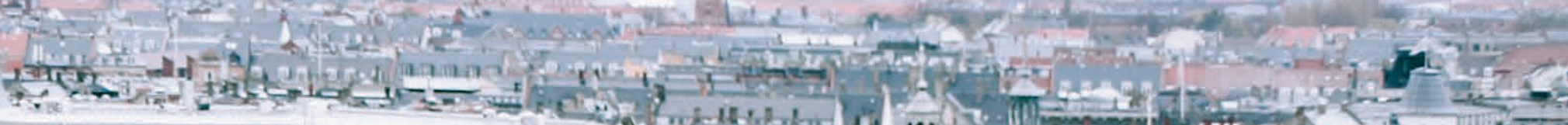

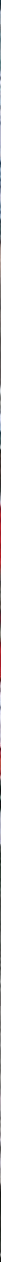





\section{THE COMPACT CITY OF THE NORTH}

- functions, challenges and planning strategies

Moa Tunström, Johannes Lidmo \& Ágúst Bogason

NORDREGIO REPORT 2018:4 
The compact city of the north

- functions, challenges and planning strategies

Nordregio Report 2018:4

ISBN 978-91-87295-63-8

ISSN $1403-2503$

DOI: http://doi.org/10.30689/R2018:4.1403-2503

(C) Nordregio 2018

Nordregio

P.O. Box 1658

SE-111 86 Stockholm, Sweden

nordregio@nordregio.org

www.nordregio.org

www.norden.org

Analyses and text: Moa Tunström, Johannes Lidmo \& Ágúst Bogason

Cover photo: Maria Orlova/Unsplash

Repro and print: Allduplo

\section{Nordregio}

is a leading Nordic and European research centre for regional development and planning, established by the Nordic Council of Ministers in 1997. We conduct solution-oriented and applied research, addressing current issues from both a research perspective and the viewpoint of policymakers and practitioners.

Operating at the international, national, regional and local levels, Nordregio's research covers a wide geographic scope, with an emphasis on the Nordic and Baltic Sea Regions, Europe and the Arctic.

\section{The Nordic co-operation}

Nordic co-operation is one of the world's most extensive forms of regional collaboration, involving Denmark, Finland, Iceland, Norway, Sweden, and the Faroe Islands, Greenland, and Åland. Nordic co-operation has firm traditions in politics, the economy, and culture. It plays an important role in European and international collaboration, and aims at creating a strong Nordic community in a strong Europe. Nordic co-operation seeks to safeguard Nordic and regional interests and principles in the global community. Common Nordic values help the region solidify its position as one of the world's most innovative and competitive.

\section{The Nordic Council of Ministers}

is a forum of co-operation between the Nordic governments. The Nordic Council of Ministers implements Nordic co-operation. The prime ministers have the overall responsibility. Its activities are co-ordinated by the Nordic ministers for co-operation, the Nordic Committee for co-operation and portfolio ministers. Founded in 1971.

\section{The Nordic Council}

is a forum for co-operation between the Nordic parliaments and governments. The Council consists of 87 parliamentarians from the

Nordic countries. The Nordic Council takes policy initiative $s$ and monitors Nordic co-operation. Founded in 1952.

Stockholm, Sweden, 2018 


\section{Contents}

Preface

6

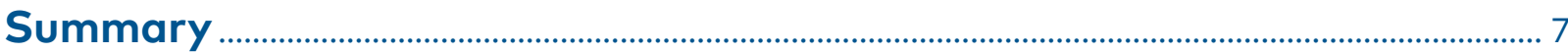

The compact city idea in a Nordic context......................................................................... 8

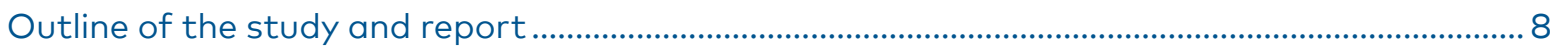

Conceptualizing urbanity ......................................................................................................... 10

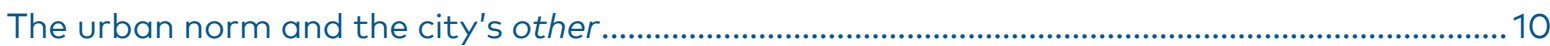

Small and medium-sized cities - concepts and definitions ..............................................................12

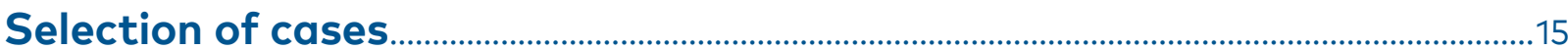

Planning and building the compact city of the north ...............................................17

City centres under pressure from external shopping .......................................................................17

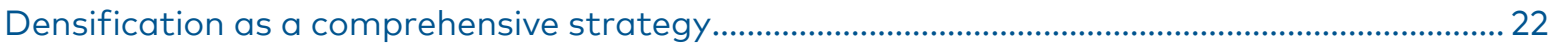

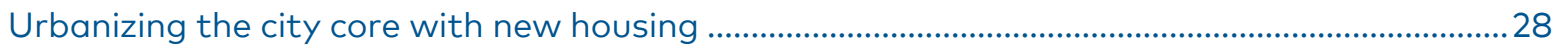

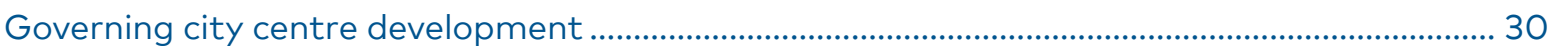

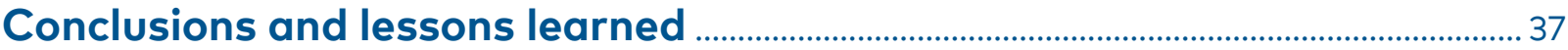

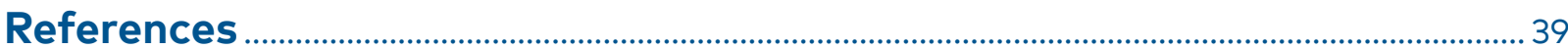

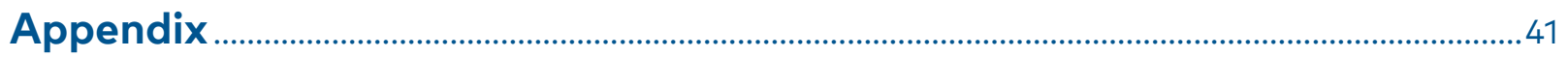




\section{Preface}

As part of the Nordic Co-operation Programme for Regional Development and Planning 20172020, three Nordic thematic groups have been established in the following areas:

1. Sustainable rural development

2. Innovative and resilient regions

3. Sustainable cities and urban development

The groups have been set up by the Nordic Committee of Senior Officials for Regional Policy (EK-R), under the Nordic Council of Ministers for Sustainable Growth, and the members are representatives of relevant ministries, national authorities, regional authorities and cross-border co-operation committees. One purpose of the thematic groups is to implement the co-operation programme by contributing to the exchange of knowledge and experience between regional policy stakeholders, by promoting Nordic perspectives and by highlighting the importance of regional policy issues for sustainable development and growth.

This report is the result of work done for the thematic group Sustainable Cities and Urban
Development. The group focuses on: 1) social sustainability and gender equality; 2) spatial planning; 3) urban qualities in small and medium-sized cities, and the urban-rural relationship; and 4) the growth and development of Arctic cities. Within these broad themes the group decides what activities to conduct, and the researchers involved are responsible for the results.

The topic of this specific report, the preconditions for the planning and development of city centres in small and medium sized cities, is an issue that is high on the Nordic spatial planning agenda, and one where there is major potential for Nordic learning.

The authors wish to thank all of the interviewees and contact persons for their valuable contributions, and all of the readers of the draft versions who helped in the final stages of the work.

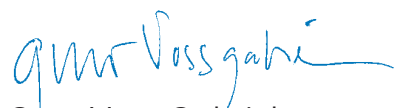

Guro Voss Gabrielsen

chair of the Nordic thematic group

Sustainable Cities and Urban Development 


\section{Summary}

In this report, the characteristics and consequences of the compact city ideal in Nordic cities, and more specifically in their city centres, are investigated. The research was done in the form of a series of small case studies of city centre development, and they are presented thematically. They focus on public spaces and the threat from external shopping, densification as a planning strategy, new housing as a planning tool, and finally governance and actor collaboration. The Nordic region is dominated by small and medium sized cities, and we chose the following cities for our investigation of city centre challenges and planning strategies: Bodø (Norway), Kokkola (Finland), Mariehamn (Åland), Mosfellsbær (Iceland), Sorø (Denmark) and Västervik (Sweden). The cities were investigated through planning and policy documents, interviews and observations, and the work was guided by the following questions: What does "the compact city" mean in the investigated cities - and how is it operationalized? What are the main planning problems related to city centres, and what are the visions for the future in relation to these? What can we learn from different ways of approaching city centre development across the different Nordic countries?

Two strong themes related to development in city centres, and to the commonly held view that the city core needs to be strengthened, regenerated or recreated, are competition from external shopping centres, and urban sprawl. These themes point to the challenges to the central city as the one and only centre. The examples from the Nordic region show that the competition from external shopping is very real, and that planning regulations do not always have the desired effect on the competition. This has led to a variety of responses - new central housing, new attractive spaces, new types of plans and new governance collaborations. In addition to their different approaches to competition from external shopping, cities employ diverse strategies to increase the critical mass of people who populate the city and its venues. There are, in many cases, very concrete geographical and material influences on city development in the past and for the future - existing buildings and functions, wetlands, railways or municipal boundaries. Related to urban sprawl it was striking how decisive the car, car use and parking needs were in the cities, despite current moves to ban cars from city centres and government goals for zero growth in private car use. Finally, we observed planning based on hope. A hope that the trend will change in smaller cities, and that people - not only the young and the elderly - will be attracted to living centrally. This makes densification and enlargement of the central city more of a planning ideal and an expression of the urban norm, rather than a response to existing demand.

This study was interested in what the city centre is, or should be, when it no longer has an obvious role. The investigations have led us to conclude that there is no essence to be found and it is instead important to understand the city centre as dynamic and constantly changing. In line with this, the importance of actor collaboration and flexible urban spaces are among the lessons learned from the study. 


\section{The compact city idea in a Nordic context}

The discourse and practice of contemporary urban planning focus strongly on densification and the compact city as the ideal and model for sustainable development. There is a pervasive "urban norm", associated with planning, development and lifestyles, in both the Nordic countries and elsewhere in Europe. According to this norm, the compact city, and life in this city, is sustainable, attractive and safe. Densification of the built environment is often said to be the singular solution to all current urban problems. In parallel, sprawling urbanism has come to symbolize the environmental, social and economic problems of contemporary cities.

The tendency to idealize the compact city, and to turn away from urban sprawl, also has a geographical component in that in many cases, it makes the traditional city centre into the ideal and the urban periphery into a planning problem. The compact city and sprawl can be understood as two sides of the same developmental trend, having impact on both planning discourse and practice in the Nordic countries and elsewhere. However, it is not evident what densification or compactness mean more specifically. Densification of what: people, buildings or services, or just certain specific functions?

In this report, we consider the characteristics and consequences of the compact city ideal, and of densification strategies for small and medium-sized cities in the Nordic countries, and more specifically for their city centres. The city centre is on the agenda, as a planning challenge, in many Nordic cities. Preconditions arise from the geographical context of northern European cities. For example, in international terms, Nordic cities are predominantly small or medium sized and the Nordic countries are overall relatively sparsely populated. In addition, the weather and the climate can be harsh, limiting the use of public spaces, especially during winter. There is consequently both a need to focus on the specific characteristics of
Nordic cities and the potential to learn from cities with similar development challenges.

It is appropriate to consider the contemporary function of the centre in smaller cities. Using Manhattan as a model does not work in a city core the size of a few blocks. Design, for appropriate function, of the central city is a key challenge when shopping has moved out to external shopping centres, business to business parks and residents to spacious outskirts. Developmental trends such as these are, of course, not brand new, but they do in fact raise questions about the very idea of a multifunctional city centre, especially in smaller cities where the centre and periphery are relatively near.

\section{Outline of the study and report}

The research on which this report is based included a series of small case studies of city centre development in small or medium-sized Nordic cities across the Nordic Region. We reviewed the planning and development challenges that each of these cities are - or have been - facing with regard to their core. The examples from the cities should not be considered as representative of their respective countries, but rather as illustrations of existing strategies in the Nordic countries. These strategies provide learning potential as a result of the various constructions of the problem and differences in planning rules and regulations, economic development initiatives, governance approaches and housing market situations. We discuss these topics around the following questions:

1) What does "the compact city" mean in the investigated cities - and how is it operationalized? 2) What are the main planning problems related to city centres, and what are the visions for the future in relation to these?

3) What can we learn from different ways of approaching city centre development across the different Nordic countries? 
This report presents the results of these investigations; first by framing our examples in a context of small and medium-sized cities. After a brief introduction to the individual cities, they are discussed under the following themes: public space and shopping, densification, housing, and governance. A concluding discussion completes the report.
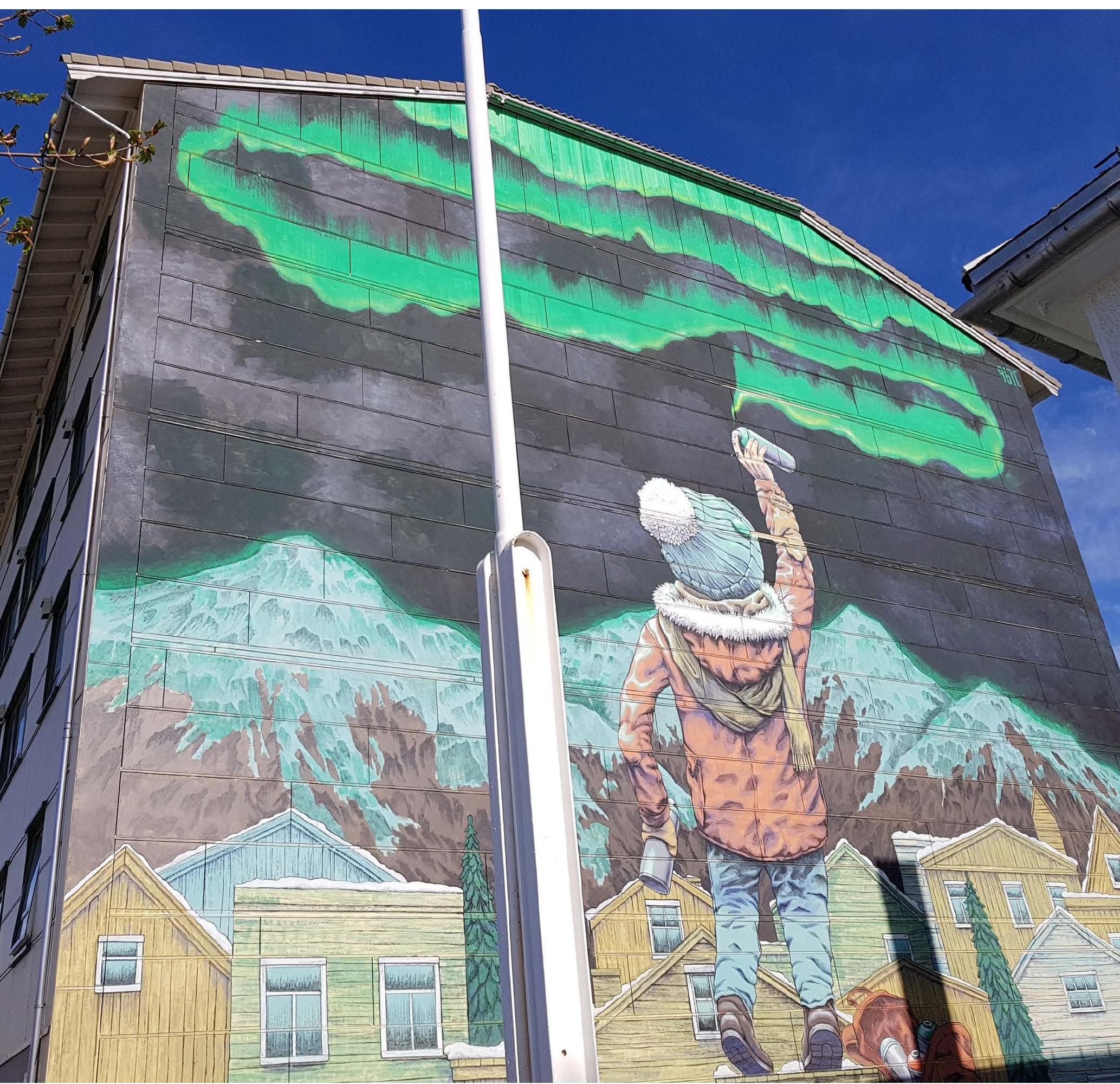

Mural in Bodø. Photo: Moa Tunström 


\section{Conceptualizing urbanity}

\section{The urban norm and the city's other}

The city core carries a lot of promises - of urban lifestyles, of economic growth and of compact, and therefore environmentally sustainable, structures. One focus of this report is to review the ongoing materialization of the compact city ideal in the Nordic countries; another is to provide greater awareness of the options for smaller cities in developing their city centres into lively and diverse environments that are attractive to both inhabitants and visitors. Both these reasons concern what is often referred to as the urban norm. When the compact urban structure or specific urban lifestyles are idealized and used as the evident frame of reference for planning and everyday life, the urban norm is in effect. Beyond the megacities and large capitals, the urban norm in planning can be both a source of inspiration and an impossible dream.

This study gives examples from ongoing planning and development in Nordic cities - developments with the purpose of bringing both residents and commercial actors back into city centres in order to create the lively urbanity that is such a strong ideal today. Bringing activities back to the city centre may be a consequence of both land-use planning measures and planning regulations, in addition to steering and governance models. The ways in which initiatives are conceptualized can also illustrate various images of the city centre. Certain measures address the centre primarily as a shopping centre, while other measures might construct it as a cultural centre or perhaps as a place to live. In any of these there can also be expressions of the urban norm, preferring planning solutions or particular logics that lead to what is considered to be a sustainable solution.

If there is a norm, there are often also deviations from that norm: that is, ideas of the other, the non-urban. The rural, the countryside, or the suburb then becomes the opposite location - the outside. This other is, in relation to idealized urbanity, regarded as the place where there is a lack of development, sustainability or growth (Tunström
2009). However, the urban has also been treated as an empty signifier, a term that can be filled with almost any meaning:

"... in the early twenty-first century, the urban appears to have become the quintessential floating signifier: devoid of any clear definitional parameters, morphological coherence or cartographic fixity, it is used to reference a seemingly boundless range of contemporary sociospatial conditions, processes, transformations, trajectories, and potentials." (Brenner 2013,90)

This lack of clear demarcation is evident in contemporary cities. It is unclear where we should look for urbanity today and how it manifests itself. People gather in many different places and there are new digital spaces that are important places of social interaction. The city centre is no longer the evident, or only, public or collective space for urban culture. So, where is the actual centre of a city today? There are airports, external shopping centres, sports fields or railway stations, not necessarily located in the city centre, but still drawing people's attention and being locations for collective urban everyday life. Add to this the sprawling settlement structure resulting from economic growth and increasing mobility through the 1900s. It has become both economically and technically possible for cities to grow outwards, and for people to have their own spacious house and garden. Businesses are global and mobile, and in need of flexible rather than central spaces. The shopping centres and storage spaces on the edges of cities give us quick access to the things we want to buy. So, in a sense, the sprawling settlements of today are both a consequence of, and an important basis for, economic growth and development. However, this is also a threat to a lively, populated and economically viable city centre, and hence the background to the commonly held view that the city core needs to be strengthened, regenerated or recreated. 


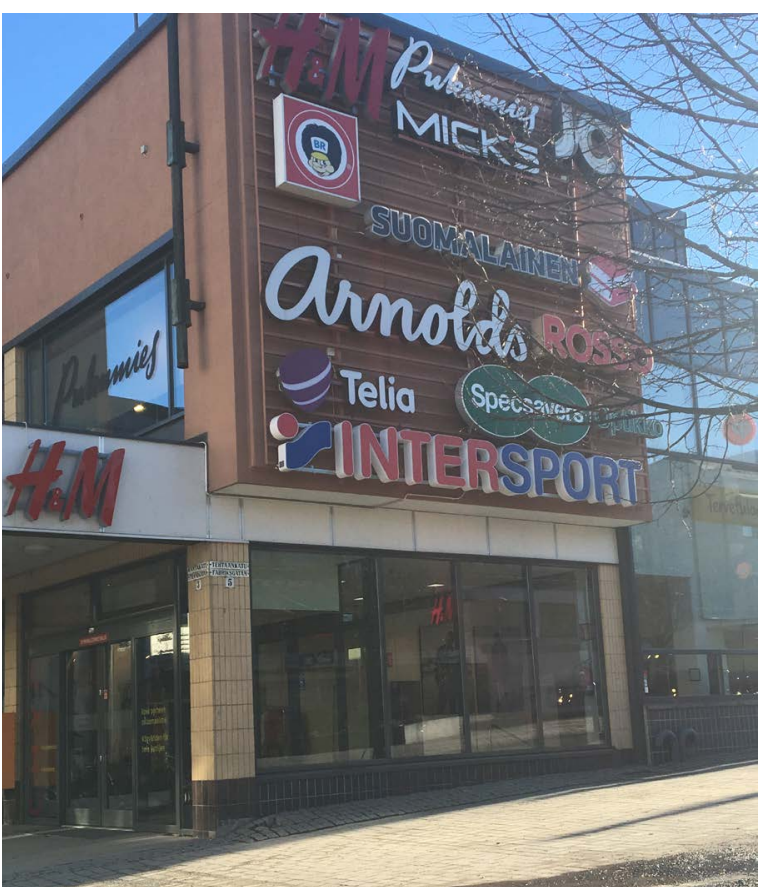

Pedestrian shopping street in Kokkola.

Photo: Johannes Lidmo

There are several examples of policy responses to the threat of sprawl in the Nordic countries. In Norway, the Ministry of Local Government and Modernisation recently published a handbook on the planning and design of urban public spaces (Kommunal- og moderniseringsdepartementet 2016) as part of its revision of the Norwegian Planning and Building Act and its "Cities of the Future" programme ("Framtidens byer"). This programme (2008-2014) focused on the reduction of greenhouse gas emissions, climate adaptation and better urban development in the 13 largest Norwegian cities. The new handbook presents the government's perspective on urban public space and urban development. It raises issues and suggests mechanisms for improving public spaces, accessibility and social interaction rather than addressing, for example, housing policy or business development. In other words, the city centre is being addressed as a network of public spaces primarily from an urban design perspective. The main focus is not on the city centre as an entertainment space or as an arena of collaboration between public and private actors. Urbanity and the city centre are considered in quite a different way by organizations actively lobbying for real estate and business owners (Norsk Sentrumsutvikling in Norway, Svenska Stadskärnor in Sweden and Elävät Kaupunkikeskustat ry in Finland). From their perspective, a city centre is first and foremost a shopping and entertainment centre.

Citizens also contribute to the co-creation of the city and help define what good urbanism is. For example, in Sweden the initiative YIMBY ("Yes in my backyard") and its Finnish counterpart Lisää kaupunkia Helsinkiin ("More city/urbanity to Helsinki") have quickly become loud voices in the urban development debate and they often promote densification and the compact city as measures to make cities more "urban". During the 2000s, YIMBY has grown from a loose network into an organization, and the Finnish network has, in a similar way, grown from a Facebook group to quite a large movement that participates in the public debate, and increasingly also influences practice. Similar organizations to the one in Helsinki have been created in other Finnish cities.

What are the reasons for these quite different actors all wanting to regenerate the city and urbanism? Just like Brenner (2013) did, Swedish architectural researcher Julia Fredriksson (2014) points to the challenges to the city centre as the one and only centre, as well as the hierarchical relation between city and countryside, or centre and periphery, posed by structural changes and increased mobility. Paradoxically - or is it perhaps the most logical consequence - planning and urban design are, at the same time, showing renewed interest in the city centre while traditional and historicist ideals in urban design have also gained ground. "Traditional" streets, small ground-floor shops and grid-structured street patterns have become the urban design model again. According to Fredriksson, this increased focus on the city core must be understood in relation to the role of the periphery. So, again, the norm and the areas of deviation are intimately related, and there are those who question whether it is at all meaningful to separate them. Instead, perhaps, we should describe the contemporary urban landscape in terms such as postmetropolis (Soja 2000) or Zwischenstadt (Sieverts 2003) - emphasizing the hybridity, the post-industrial nature and an urban landscape characterized by mobility?

Many authors have been influential in the construction of the urban norm. For example, Jane Jacobs' (1961) "The Death and Life of Great American Cities" is, despite its age, repeatedly mentioned as a core narrative of the compact and mixed city, and as providing a model for contemporary urban development. More recent authors 
include Richard Florida (2002) who introduced the city as the place of creativity, and Edward Glaeser (2011) who wrote about "The Triumph of the City". Among urban design-oriented references of importance, the Danish architect Jan Gehl should be mentioned. He has written repeatedly about populated and dynamic public space, filled with attractions for the urban consumer and flâneur (e.g. Gehl 1971 and 2010). Florida and Glaeser are clear examples of marketing as a part of contemporary urban discussion (Fredriksson 2014). They understand the city as a product, on a competitive market, for inhabitants, businesses and tourists; and this, of course, influences urban development strategies. Today, both Jacobs' and Gehl's narratives need to be read in this context of place marketing and the city as a commercial space, even though they were originally more concerned about social life in the streets.

Following this commercial logic, or discourse, the city centre is a depoliticized space. This means it is not a place for struggle, conflict or political debate (Tunström \& Bradley 2015). Instead, it is emphasized as a living room or a space for the flâneur (Olsson 1998, Regionplanekontoret 2010). Public space is then primarily somewhere to meet and interact with friends, rather than being necessarily an active public space. Depoliticization does not, however, mean that urban outcomes are not a political issue, or a consequence of politics (following e.g. Mouffe 2005). Rather, it means that it is important to keep in mind that even though the commercial logic is dominant in an era of city marketing and intercity competition, there are other possible drivers as well - e.g. the city as a space for political debate, or the city as a place to live. These differences can be particularly important when studying and analysing urban development. What types of cities, centres and citizens are considered in plans for livelier city centres in, for example, Mariehamn, Bodø or Västervik in the Nordic Region? What types are hidden or not encouraged? What are the concepts used in the policy documents from Kokkola or Sorø is the aim "living room", "public space" or "compact city"? What are the arguments behind the need to strengthen the city core in Mosfellsbær, and are they environmental, economic or social?

\section{Small and medium-sized cities - concepts and definitions}

In recent years, increased scholarly and policy interest in small and medium-sized cities is evident (see e.g. Servillo et al. 2014; Servillo et al. 2017; Nordic Council of Ministers 2017). In the Nordic Co-operation Programme for Regional Develop-

The central square in Mariehamn. Photo: Johannes Lidmo

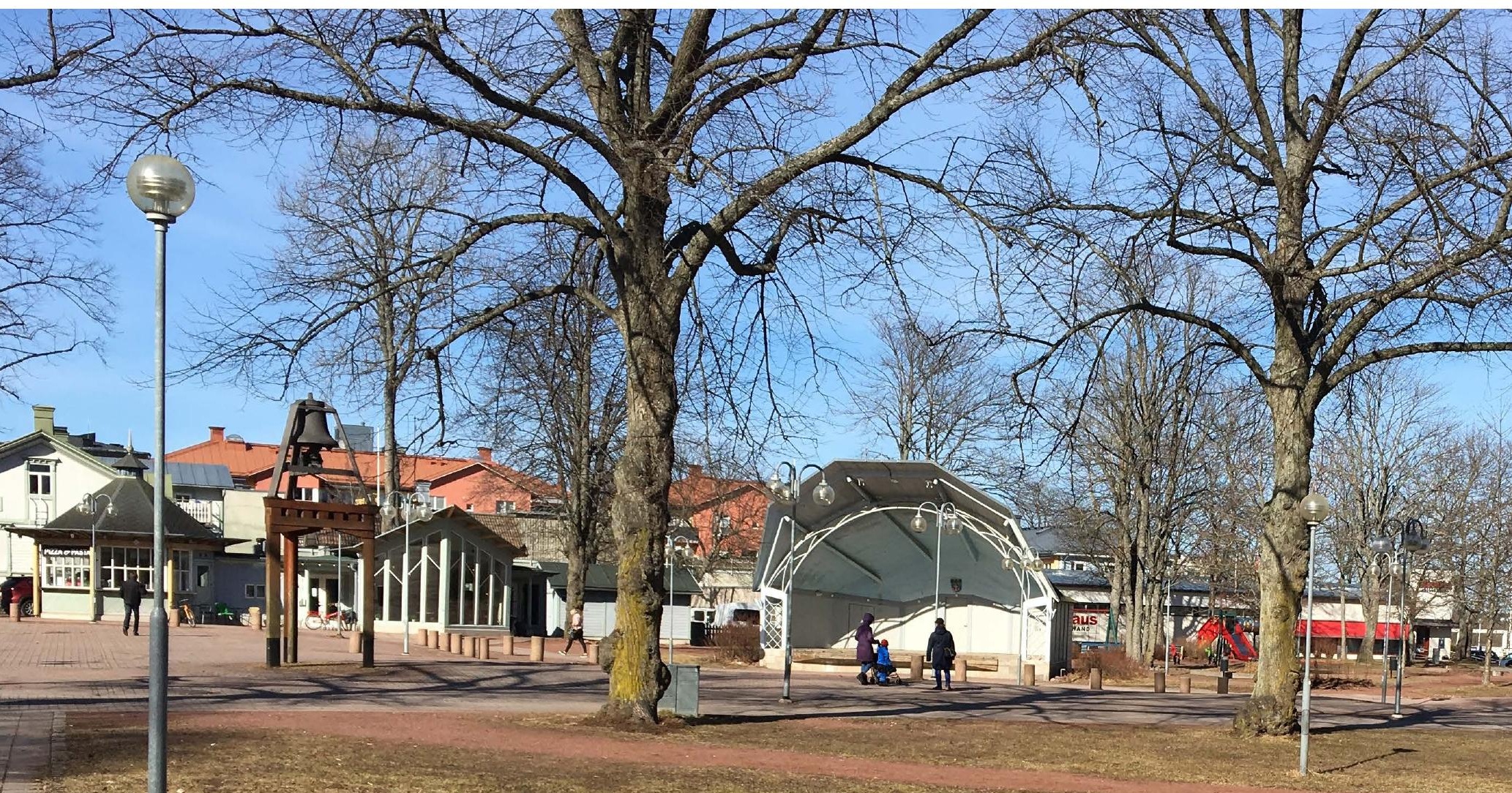


ment and Planning (Nordic Council of Ministers 2017), small and medium-sized cities have been designated as being of particular interest. It is less clear, however, what exactly a "small" or a "mediumsized" city is. As Smas $(2018,44)$ notes: "Small and medium-sized cities can be defined in many ways and there is no (and cannot be) one universal definition mainly because it is a relative concept with different meanings and implications in different contexts." Even if there cannot be a universal definition, there have been several attempts. In the Nordic Region, several authorities have variously defined small and medium-sized cities according to their own needs (Smas 2018). However, conceptually, there are at least three approaches: 1) the morphological approach, 2) the administrative approach and 3) the functional approach (Servillo et al. 2017). The morphological approach refers to coherent built-up areas, concentrations of buildings and population sizes above a minimum threshold. The administrative approach is based on the administrative divisions of cities. The functional approach reflects the functions in an urban centre/urban core, or over a functional region (Servillo et al 2017). A centre/core then encompasses an urban settlement where jobs, services etc. are concentrated, whilst a functional region is a larger area with one or several cores.

Defining cities using the functional approach could be difficult on a Nordic or European scale since it requires detailed local data. The administrative approach remains commonly used, and most countries provide their population statistics within these units. However, Nordic municipalities often include both urban cores and rural hinterlands, making the administrative approach imprecise when it comes to determining the size of a city. In 1960 the national statistical offices in the Nordic countries therefore agreed to define urban settlement using a morphological approach (SCB 2009, 83). Urban settlement corresponds to the terms tätort (SE), byområde (DK), taajama/tätort (FI), Péttbýlisstaður (IS) and tettsted (NO) (Smas 2018).

"In the Nordic Region, the population threshold is 200 individuals living within 200 metres (in Norway 50 metres) of each other. The delimitation of the urban settlement is regularly updated to account for settlements growing together and/or growing apart" (Smas 2018, 39).
Using this threshold, only a small population is required for an area to be defined as an urban settlement, and the definition does not take aspects such as population density into consideration.

A Europe-wide definition of small and mediumsized cities was attempted a few years ago through the European Observation Network for Territorial Development and Cohesion (ESPON) programme. The so-called TOWN project ${ }^{1}$, within the ESPON programme, elaborated the different ways cities can be defined and used the morphological approach to examine population and development trends. In seeking to define different types of cities, grid-level data, with squares of 1,000 $\times 1,000 \mathrm{~m}$, were used to identify cities morphologically. The project based its typology on both population density and total population. Following the proposed typology, small cities ranged from 5,000-25,000 people and medium-sized cities from 25,00050,000 people - both with a population density of at least 300 people $/ \mathrm{km}^{2}$. The project also proposed a category called "very small town" with less than 5,000 inhabitants, but with a population density larger than 300/ $\mathrm{km}^{2}$ (Servillo et al. 2014).

Furthermore, cultural, linguistic and historical connotations associated with the terminology of a city are also important to consider. For example, the

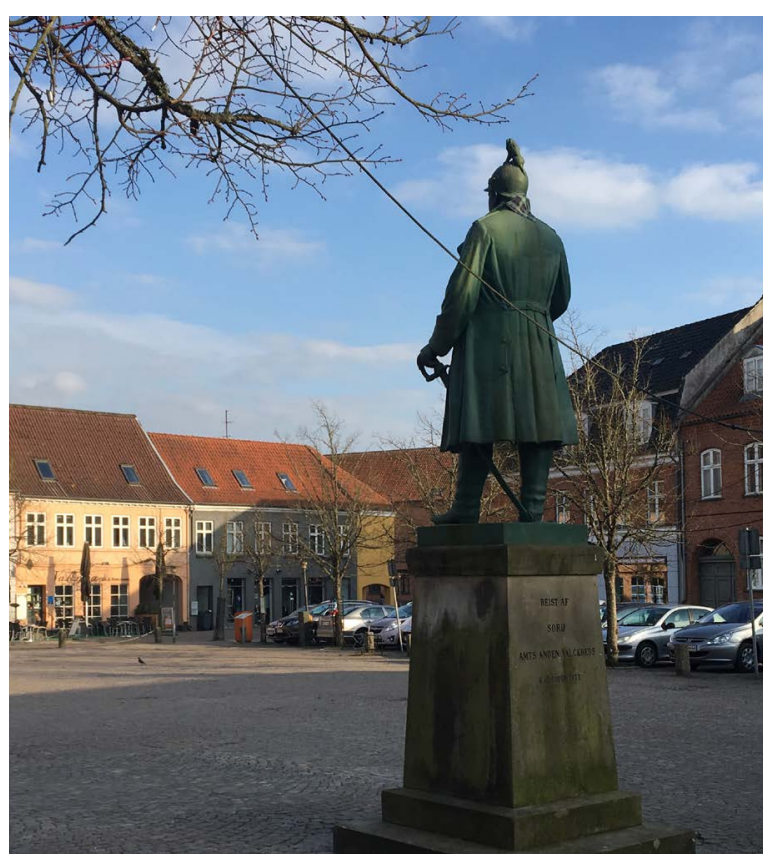

The central square in Sorø. Photo: Johannes Lidmo 1 For more information on this and other ESPON projects,
see www.espon.eu/programme/projects/espon-2013/ applied-research 
Danish and Norwegian languages use the term "by" for all urban areas (including cities), but in Swedish the same term, "by", explicitly corresponds to a village. In English the term "town" "may be considered as something 'in between' a city and a village" (Smas 2018, 44).

Although a universal definition of small and medium-sized cities is problematic, an understanding of their role and importance is nevertheless appropriate. As is noted by Damsgaard $(2006,4)$, urban areas, particularly small and medium-sized towns "are crucial in the effort to counteract the polarization of urban growth and maintain the settlement pattern, especially in more sparsely populated areas". Urban areas located within sparsely populated regions can play a key role in ensuring a minimum level of services while also diversifying the economic base (Damsgaard 2006, 4). Moreover, as argued by Bell and Jayne
(2009), it is important for both policymakers and researchers to pay attention to small cities in order to gain a nuanced understanding of what may be considered as distinctly urban, while retaining its smallness. In this study, we aimed to contribute to such a nuanced understanding of cities and urban life. We examined the planning challenges and strategies applied in the city centres of small and medium-sized Nordic cities. We use the term "city" for all our cases, regardless of whether they are categorized as cities or towns. However, we sometimes also use the generic term "urban settlement" that refers to the Nordic statistical definition of urban areas using a morphological approach (see above). The city core or city centre is a broad term; it is sometimes spatially defined by the municipalities and serves as the basis for regulating urban planning and development. 


\section{Selection of cases}

Six cities located across the Nordic Region were selected to serve as examples for this study. They are all cities with development challenges related to their central areas, and where the municipality has taken initiatives to develop the city centre to attract both business and citizens. The cities are geographically spread across the region and are located in all five countries, although they are not necessarily representative of their country. Rather, they should be considered as illustrations of ongoing urban development practices in the Nordic Region. The geographical location of the cities studied ranges from Bodø, above the Arctic Circle in Norway, to Sorø in Denmark. Another criterion was the size of the city and the municipality. As outlined in the sections above, there is no universal definition of small and medium-sized cities, but the proposed typology from the ESPON TOWN project (Servillo et al. 2014) was useful, providing us with the single category of small and mediumsized cities with 5,000-50,000 inhabitants.

Another important feature to consider when studying small and medium-sized cities is the geography and the regional context (Damsgaard 2006). Mosfellsbær is a relatively large city on an Icelandic scale, but small in an international comparison. It is situated on the outskirts of the capital area, which makes it rather like a suburb of Reykjavík, even though it is considered a city on its own. That context however influences the potential urban life, e.g. the availability of public and commercial services. In Iceland, Mosfellsbær is also the seventh-largest municipality and the population has increased rapidly in recent years. The main planning challenge in Mosfellsbær relates to development of a formal city centre with a concentration of commercial and service buildings supporting the entire municipality. The municipal plan from 2009 (Mosfellsbær 2009) has a specific focus on developing the city centre.

Sorø municipality in Denmark consists of several small cities and villages. We focused on the urban settlement of Sorø, including nearby Frederiksberg, 2-3 km south of the centre of Sorø on the railway. The two urban settlements are divided by wetlands and lakes. Sorø is located within commuting distance of both Copenhagen and Odense, and well connected to them by train. In 2016, about 11,000 people lived in Sorø

\begin{tabular}{l} 
Table 1: Inhabitants in the city core, the urban settlement and the municipality in the \\
selected cities. \\
\hline Mosfellsbær
\end{tabular}

Data source: The statistical institutes of the Nordic countries, and, for the city cores, interviewees and planning documents. 
and Frederiksberg. For the city, the challenge is to make the city centre more attractive for shops and visitors. To this end, the city has developed a specific Masterplan for Sorø (see Sorø Kommune 2012).

Bodø in Norway is located in the region of Nordland, and functions as a regional centre. In 2016, about 40,000 people lived in the urban settlement. Bodø has historically grown outwards along the transportation axis to the east, where the university is located. The current municipal plan (Bodø Kommune 2014) was adopted in 2014 and represents a policy change on matters of city centre development.

Västervik is located on the east coast of Sweden and is surrounded by large rural hinterlands. About 21,000 people lived in the urban settlement in 2016, and it is branding itself as the "archipelago city" ("Skärgårdsstaden"). Västervik is also an old city with national cultural heritage status. In the past ten years, city efforts have been directed towards developing the attractiveness of the city centre; in 2017, it won the award for Sweden's city centre of the year. ${ }^{2}$

Kokkola (Karleby, in Swedish) on the west coast of Finland had an urban settlement popu- lation, in 2016, of about 36,000. Historically, Kokkola has grown outwards, increasing the demand for infrastructure and public and commercial services. Despite its sprawling structure, the city lacks public transportation. Improvement of the city centre has received special attention in recent years. A designated development plan formulates the vision of a more attractive city centre (Isotalus 2016).

Mariehamn is essentially the only city in Åland, functioning as a node for several important governmental institutions. Mariehamn is also a centre of employment, and therefore a commuting city. The municipality is small and has historically grown outwards, making the settlement's population larger than the population of the Mariehamn municipality. The main challenge for Mariehamn is competition from a shopping centre in the neighbouring municipality.

The cities were investigated through studies of central planning and policy documents, interviews and observations. The interviews were with individuals or groups, including planners, civil servants and people from the business sector. All, except the Icelandic ones, were conducted during our on-site study visits. The main data collection took place during spring 2018.

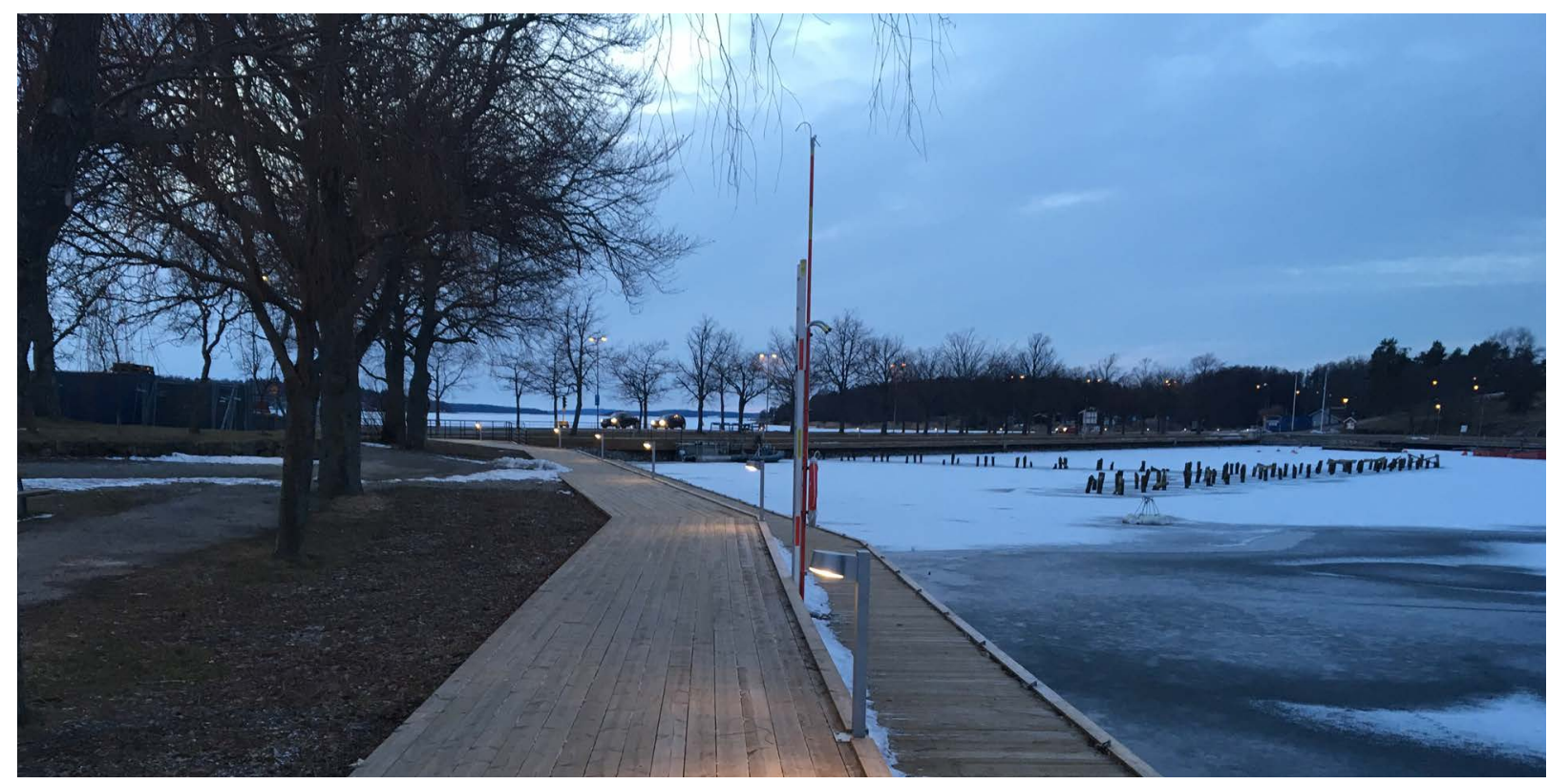

The waterfront promenade in Västervik. Photo: Johannes Lidmo 


\section{Planning and building the compact city of the north}

\section{City centres under pressure from external shopping}

The central parts of the cities that we investigated are all in different stages of transformation, with differing planning challenges. Central Bodø is currently under transformation from a shopping centre to a mixed district with shopping, housing and cultural amenities, and there are plans for a new housing district on a former airfield that will enlarge the central city. In Västervik, many years of work have resulted in the establishment of functioning collaboration between property owners, the city and commercial actors in the city centre (see more below) - and an award as the Swedish city centre of the year 2017. Kokkola has a vision for a changed city image, with the development of a completely new district. In Mosfellsbær, the challenge is to create a completely new city centre where little currently exists. Several of the cities have a common challenge, closely related to the role and function of public space, of addressing the competition from external shopping. They are seeking to make the city centre attractive for reasons other than shopping, or to find a complementary role for the central area, side by side with external centres. This chapter explores Nordic city centre development practices thematically. The themes address the ways in which cities densify and how they govern city centre development. In this first section, the focus is primarily on the current functions of the city centres.

In the interviews with planning officials from the cities, we were interested in what they perceived as the city centre. In some of the cases this was obvious. There is an administrative border delimiting the city core from the rest of the city, imposing certain planning rules and regulations on land inside the border and others outside it. In other cases, the city centre is not administratively defined - making city centre development an arbitrary concept. Our study was concerned with how the city centre is perceived and discursively constructed through planning, and not with administrative boundaries. Within this process, however, rules and regulations can have great importance in parallel with visions and ideals. The obvious example here is Bodø, where in 2014, the city removed the planning regulations that had made it impossible to build housing in the central parts of the city ${ }^{3}$ (see more below). This changed what the city centre can be, from primarily a shopping centre to a more mixed environment.

In Mariehamn, the interviewees had a few different definitions of the city centre. Either it was the area of a few blocks that is covered in a plan for the central city, or it was just one street, Torggatan. They also brought up another issue of importance for both the perception and the construction of the city centre - rent levels. The rent is highest along the main street, Torggatan, and then successively lower in the adjacent streets.

However, when the planners in Mariehamn talk about development strategies for the city centre they refer to more than the main street. They want the intensity of the main street to spread out to a larger area, and they want to add housing. They talk about bringing more life to a centre that today is dead. They also bring up the ever-present conflict, when it comes to city centre development, between cars and urban life:

"The car is our biggest problem. It stops all development and everything. (...) Otherwise, there is quite strong consensus among politicians and public officials that we want a liveable city, we want a secure city, we want a lot of people living in the city." 4 


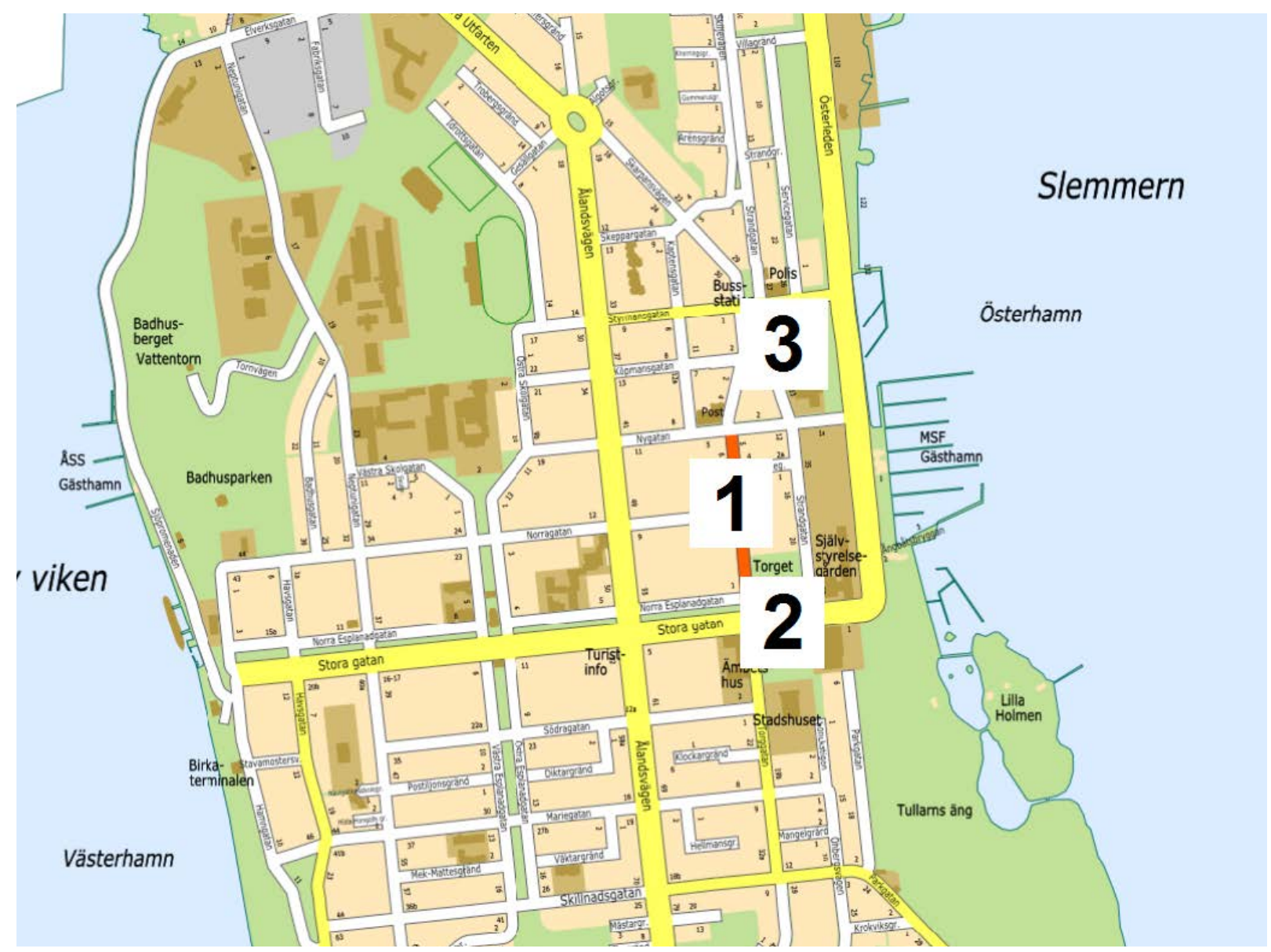

Figure 1: Map of Mariehamn city centre and its important public spaces according to interviews and observations. 1: The street Torggatan (partly a pedestrian zone); 2: The square; 3: The public space, Biblioteksplatsen. Edited map, based on map from Mariehamn Map Service. ${ }^{5}$

In the planners' understanding, attractiveness is related to public spaces without cars. However, cars are very much present in the contemporary city, and the municipality of Mariehamn needs to accept that as well. The question is, according to the local planners: should they plan to make the centre inaccessible to cars?

The planners in both Bodø and Kokkola revealed similarly varying understandings of what constituted the city centre - only the immediate shopping streets, or also surrounding residential areas. This is not just a sign that the borders are indistinct but can also be understood as a negotiation of the role of commerce in a city. Is the centre just for shopping, or can you also have residents in a centre?

The ambition in Kokkola is to make the centre into a living room, and part of the strategy for

5 Source: https://karta.mariehamn.ax/ims achieving this is to fill the city with attractive events and experiences. According to our interviewees in Kokkola, the city centre should function as an extension of the home, with cafés and public spaces as social arenas. The barriers to this outcome are mainly practical. Collaboration, both within the city administration and with other actors, is required to ensure that public spaces can be used in attractive ways - for markets, concerts etc.

Mosfellsbær's municipal plan (Mosfellsbær 2009) envisages creating a city centre in a designated area, defined by the crossing of two streets. Currently, the public spaces of importance in Mosfellsbær are situated outside of the city and mostly oriented around outdoor activities such as horse-riding and bird-watching, and the centre has been very car-friendly. The plan is to create more life in the city and encourage people to spend time there - either as residents or as customers, and not necessarily in their car. The planners are trying to densify and adapt Mosfellsbær to its rapid 
growth as it transforms from a rather sparse and rural municipality into a city. The interviewed officials said that it has always been "countryside within the city", but that this image is now about to change. They hope, and believe, that it will become attractive to live in the city centre, both for young families and older people who want to sell a house and move into an apartment. In the municipal plan (Mosfellsbær 2013) it is stated that the city centre shall consist of commercial and public service buildings for the municipality as a whole. It is also stated that it should be possible to allow residential property on the upper floors of new buildings, and there will be housing near the immediate centre. The new buildings will be relatively low-rise, with 2-4 storeys, and include ground- floor or basement garages. The plan further envisages a new cultural centre, including a church, as a landmark building.

In Bodø, an important location in the city centre is the so-called Glashuset. It is part of a central shopping street that has been covered with a glass structure since the 1990s, giving it a character similar to that of an indoor shopping centre. This has long been, and remains, an important "public" space that protects visitors from rain and harsh weather. Another important and more recent addition to the city centre is the cultural centre Stormen, which includes a concert hall and a public library. Stormen has had an enormous impact on the life and the vitality of the centre and the city alongside the water in Bodø. ${ }^{6}$

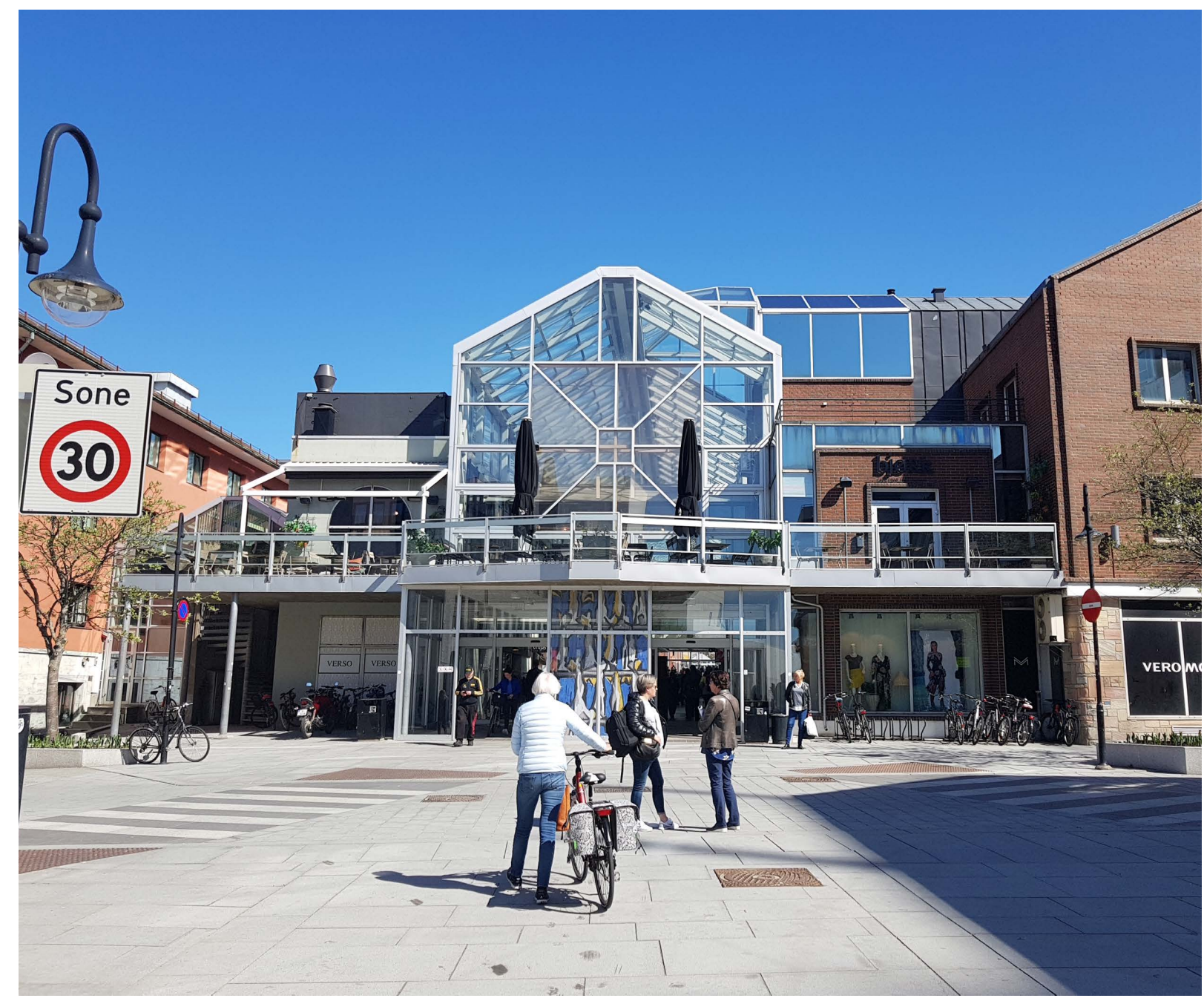

The so-called Glashuset ("The Glass house") in Bodø, an indoor shopping street. Photo: Moa Tunström

6 Source: Interviews 8 and 9, see appendix. 


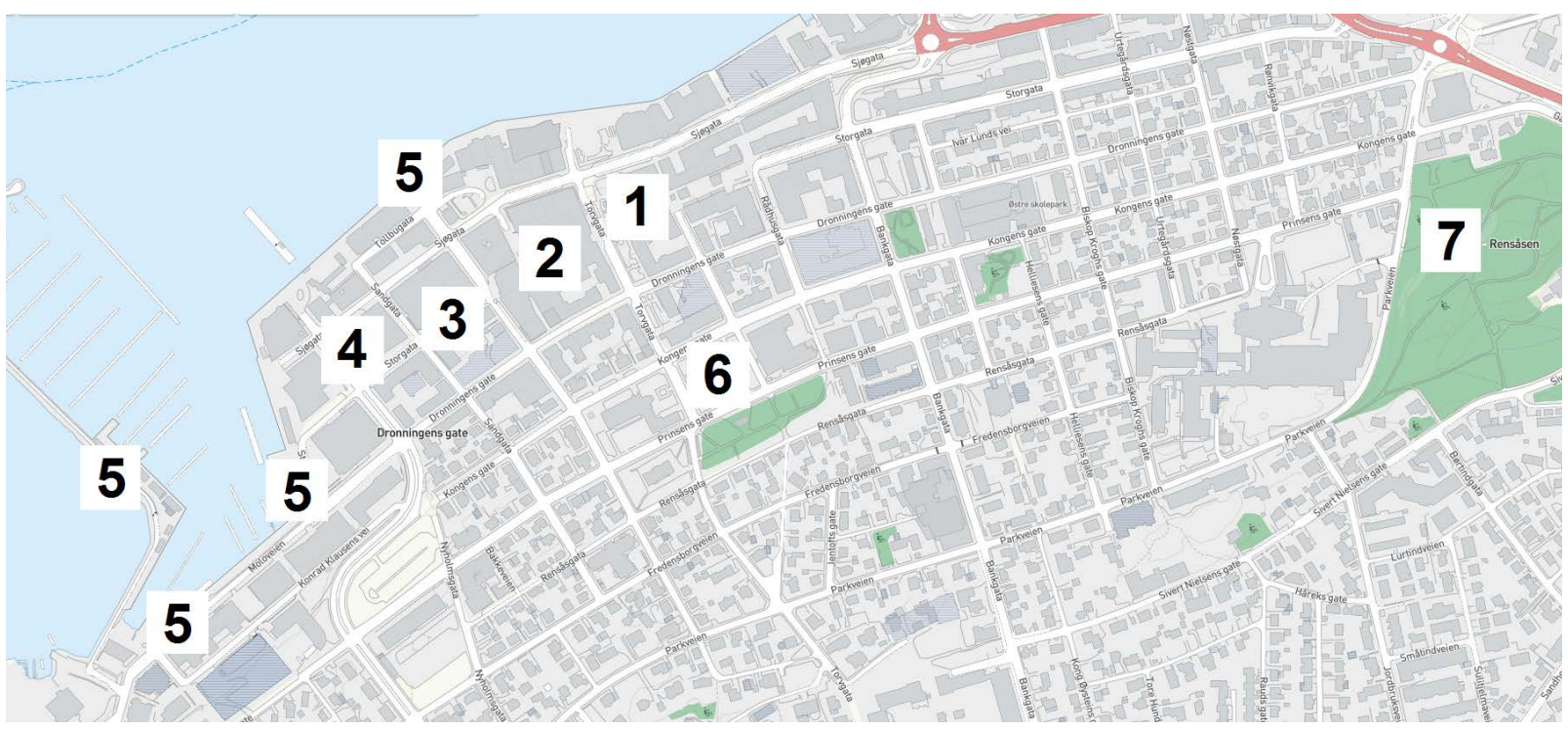

Figure 2: Map of Bodø city centre and its important public spaces according to interviews and observations. 1: The square; 2: The indoor public street Glashuset; 3: The cultural centre Stormen; 4: The pedestrian zone of Storgata; 5: The waterfront promenade; 6: The public park Rådhusparken; 7: The public park Rensåsparken. Edited map, based on map from Bodø Map Service. ${ }^{7}$

\section{Planning legislation for retail development in Norway and Denmark}

When considering the city centre of Bodø, it is important to recognize that the "external" shopping centre, City Nord, is in practice barely external, being situated on the edge of the city. In that sense, it is very much a competitor to the city centre. In the following section, we focus specifically on retail planning legislation in Norway and in Denmark, since both countries regulate commerce as part of their urban development processes.

In the Nordland region of Norway, there is a regional regulation (valid until 2023) based on a national guideline that prohibits the establishment of shopping centres larger than 3,000 $\mathrm{m}^{2}$ outside of a defined city centre zone (Regional planbestemmelse 2013). The exception is if the shopping centre is in a regional centre such as Bodø. It is, however, noted in the regulation that the establishment of shops should, as a rule, be in the city centre. To establish shopping areas outside the defined city centre zone, the municipality needs to consider various aspects, including commercial needs and distances to the city centre for pedestrians, bicyclists and by public transportation. In Bodø, the shopping centre City Nord was established in 1994, just outside the defined city centre zone. It has been extended twice since, and today has 105

7 Source: http://kommunekart.com/klient/bod\%C3\%B8 shops and a total of $66,000 \mathrm{~m}^{2}$ floor space (City Nord 2018) very near the central part of Bodø. The ongoing development of the city centre, with the new cultural quarters and the waterfront promenade, can be considered as a contemporary reaction to the robust competition from City Nord: the intention is to compete by providing attractions beyond shopping.

Danish planning legislation also has restrictive regulations on retail development outside the city. The legislation distinguishes between shops for daily needs and those for large durables (Erhvervsstyrelsen 2017). Another important distinction in the planning legislation is between city centres and other potential commercial locations, such as district centres or areas outside of the city. The categories are:

City centres: Here, the boundaries must be based on the presence of the number of functions, including shops, cultural services, private and public services. Only one city centre can be defined in each city. A maximum of $5,000 \mathrm{~m}^{2}$ for shops for daily needs is allowed.

- Local centres and single shops: Permitted to provide services to a limited part of a city, a village, a summer residence area or similar. A maximum of $1,200 \mathrm{~m}^{2}$ for shops for daily needs is allowed.

- Areas for shops that deal with particularly voluminous items or goods that present a special safety risk. 


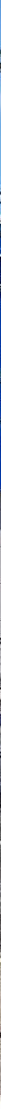

The shopping centre City Nord in Bodø. Photo: Moa Tunström

District centres in cities with more than 20,000 inhabitants: Here, the boundary should be based on the presence of a number of functions, including shops, cultural services, private and public services. The size of the city district centre must be determined based on the size of the district to be served. A maximum of $5,000 \mathrm{~m}^{2}$ for shops for daily needs is allowed.

- External shopping centres ${ }^{8}$ : May be located in cities where there is a sufficient customer base. The purpose is, for instance, to provide space for shops that cannot be easily placed in the city centre (Erhvervsstyrelsen 2017, 6).

Thus, Danish municipalities are quite limited in what they can permit. The purpose of this planning legislation is to ensure viable city centres. The legislation also aims to promote a varied selection of shops in small and medium-sized cities, accessibility to retail areas by strategic location of shops, and creation of efficient patterns of shops and well- functioning markets (Erhvervsstyrelsen 2018). The definition of a district centre depends on there being a sufficient population in the area. In Sorø municipality, for example, all the cities and villages are all too small to allow the establishment of district centres and external shopping centres.

The existing regulations in Denmark and Norway are obvious reactions to the threat from external shopping, while seeking to also provide for the residents' daily needs within walking distance. They illustrate the ambition to recreate or maintain lively city centres. However, the examples from both Bodø and Sorø indicate that the regulations do not always have the desired effects. In Bodø, the way the regional regulation is implemented reflects ongoing disagreement between the region and its municipalities about how much local development can, or should, be controlled by the region. The region is, however, aware that municipalities may find it hard to decline an offer to establish a shopping centre outside the defined central zone. ${ }^{9}$

8 The direct translation of the Danish term aflastningsområder would, perhaps paradoxically in the context of external shopping as a threat to city centres, be "areas that reduce the pressure on the city centre".

9 Source: Interview 7, see appendix. 


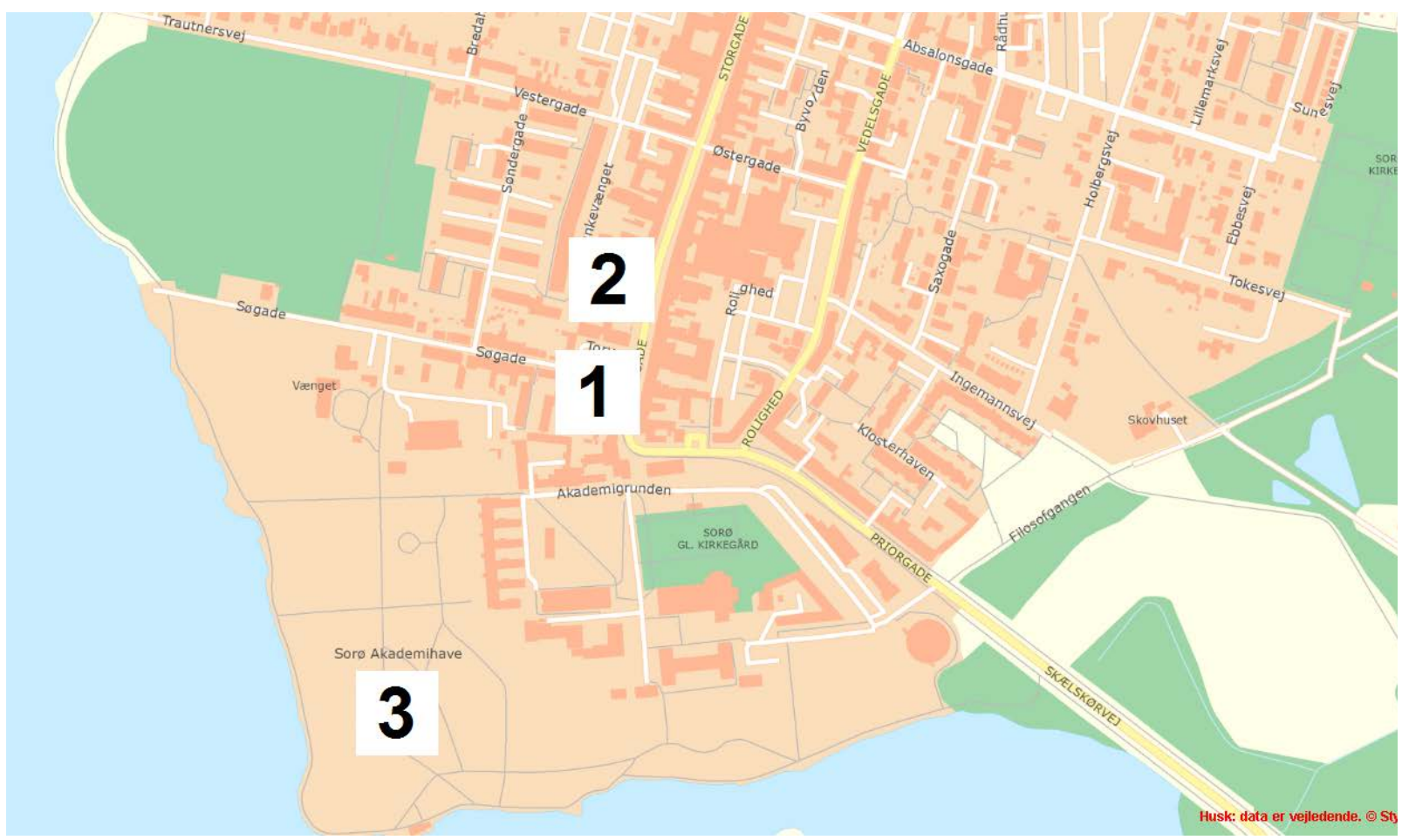

Figure 3: Map of Sorø city centre and its important public spaces according to interviews and observations. 1: The square; 2: The public space Biblioteksgården; 3: The park by Sorø Akademi. Edited map, based on map from Sorø Map Service. ${ }^{10}$

The interviewees in Sorø claimed that the regulation of retail commerce under Danish planning seems to work quite well in comparison with their observations of, for example, Sweden. Despite that, it is evident that Sorø struggles to maintain a lively city centre. As an example, when one of the local supermarkets moved to a so-called "local centre" about two kilometres away from the city centre, and another opened nearby soon after, the city centre suffered negative effects. ${ }^{11}$ This example illustrates that the relocation of a shop supplying daily needs, which attracts a steady flow of customers, can have a major impact on neighbouring commercial activities. It also illustrates that the Danish planning regulations do not always have the desired effect in smaller cities. Even if external shopping is restricted, commercial growth in local centres can have the same negative effects.

In sum, the examples from Sorø and Bodø illustrate that even though the rationale behind the regulations is to ameliorate the challenges and threats from external shopping, this is not always the outcome.

10 Source: soroe.dk/om-kommunen/soroekortet

11

\section{Densification as a comprehensive strategy}

In addition to their different approaches to competition from external shopping, cities employ diverse strategies to increase the critical mass of people who populate the city and its venues. They seek to densify, concentrating more people, buildings and activities in the centre. This materializes differently depending on the preconditions of a specific city. As we describe below, there is variation even among small and medium-sized cities in the Nordic Region. There are, in many cases, very concrete geographical and material influences on city development in the past and for the future - existing buildings and functions, wetlands, railways or municipal boundaries. Conceptualizing these influences only as barriers is however too negative, since they also offer qualities such as landscape interest, connectivity and cultural history - i.e. reasons for a specific kind of small-town attractiveness. Nevertheless, they can function as barriers to a growing or coherent city centre.

In the Danish city of Sorø, the main constraint on the development of the city centre is the landscape and its characteristics. The geography, with nearby lakes and wetlands, divides the city into two parts - Sorø and Frederiksberg - and limits its 
outward growth. Consequently, there is a desire to create attractive conditions in both "centres" of the city - the core and the built-up area around the railway station - and to concentrate housing development in other parts of the municipality. It is difficult to divert traffic from the city by building a ring road, while the traffic running through the city centre also supplies the shops with customers. According to our interviewees, the business owners consider it important that people can park on the street by the shops. In addition, Sorø's cultural heritage, the historical city structure with its old buildings along the main road running through the city, is the source of recurrent debates about preservation vs. development. This small-town deadlock situation is a challenge for both planners and developers. These environmental and cultural heritage qualities limit the development of Sorø into anything more than a small satellite to other cities. Västervik in Sweden also needs to consider its built cultural heritage when developing the city centre. In the old city, that heritage has national interest status, which means that the state has a voice in how it is regenerated or developed. However, in this case, the heritage appears to have greater value as a brand and an attraction than in Sorø. The brand derives from the archipelago location, the small-town character and conviviality.

Sorø is an example of a Nordic city that is unable to compete with larger cities, and instead must develop the particular qualities of a small city.
Even so, one of the available development strategies is densification through housing. Even though the planners state that there is basically no room for more housing in the core, which is already quite compact, 20 new apartments are planned in order to attract more residents to the centre. This development is also intended to diversify the housing by providing more small apartments, something currently lacking. Apart from other small additions, the main development area is south of the primary city core in nearby Frederiksberg, where more than 250 new units are planned.

In the Finnish city of Kokkola, a barrier to development has been the railway that cuts through the city. It has shaped development and divided the city into two parts: one with housing and urban functions, and one with industry, storage and logistics - a no-man's land, according to the interviewees. In order to densify and tie together the centre, the city is proposing substantial redevelopment of this brownfield area, making new central land available for both housing and commercial development. The goal, according to the interviewed planner, is to increase the area's attractiveness through apartment buildings, highquality courtyards, boulevard-like streets with little traffic and a great deal of green space.

To make the city more attractive, Kokkola has both a specific development plan for the city centre (Isotalus 2016) and a development strategy for the city as a whole (Karleby stad 2017). The ambition is

The main street in Sorø, where a lot of cars pass through. Photo: Johannes Lidmo

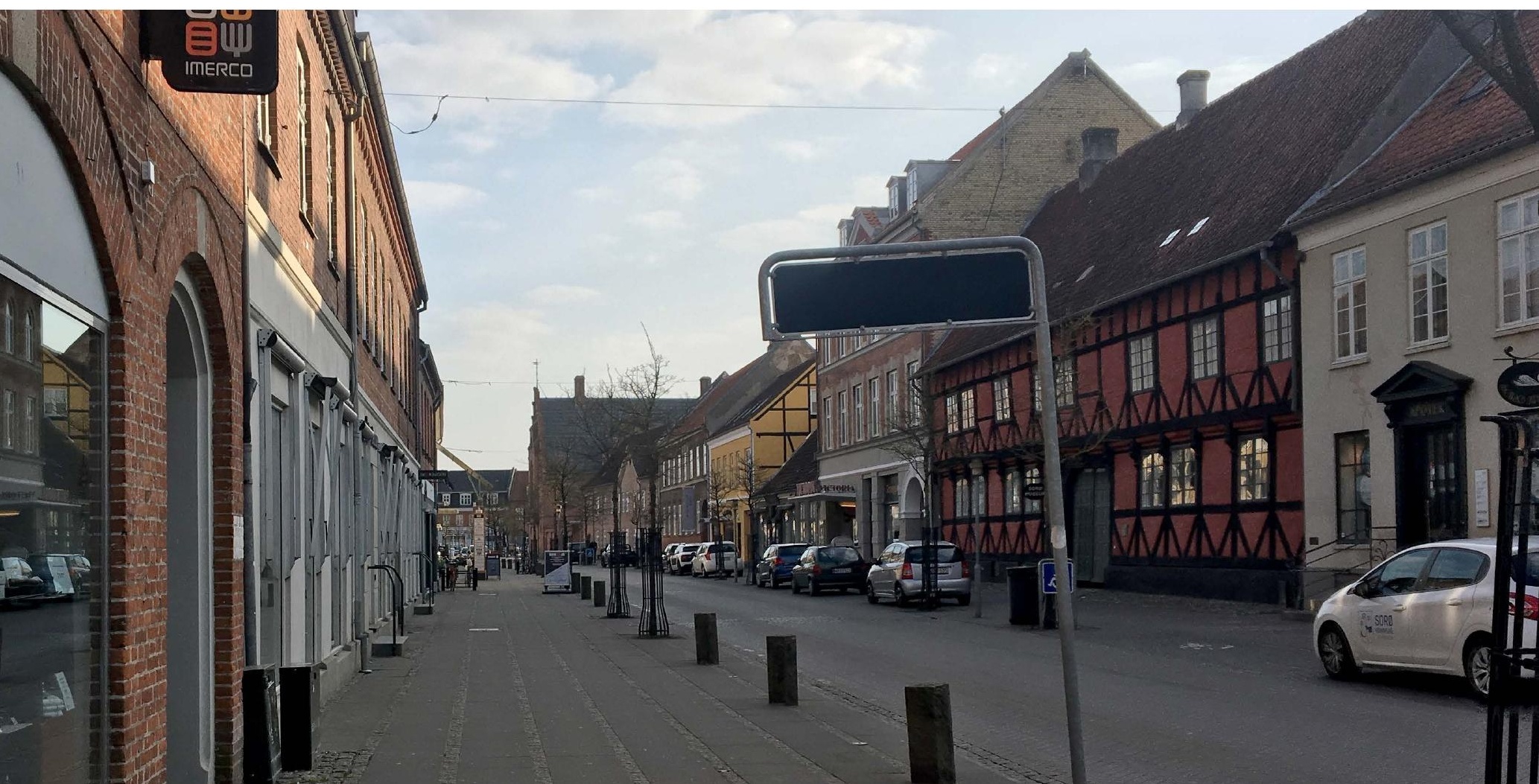




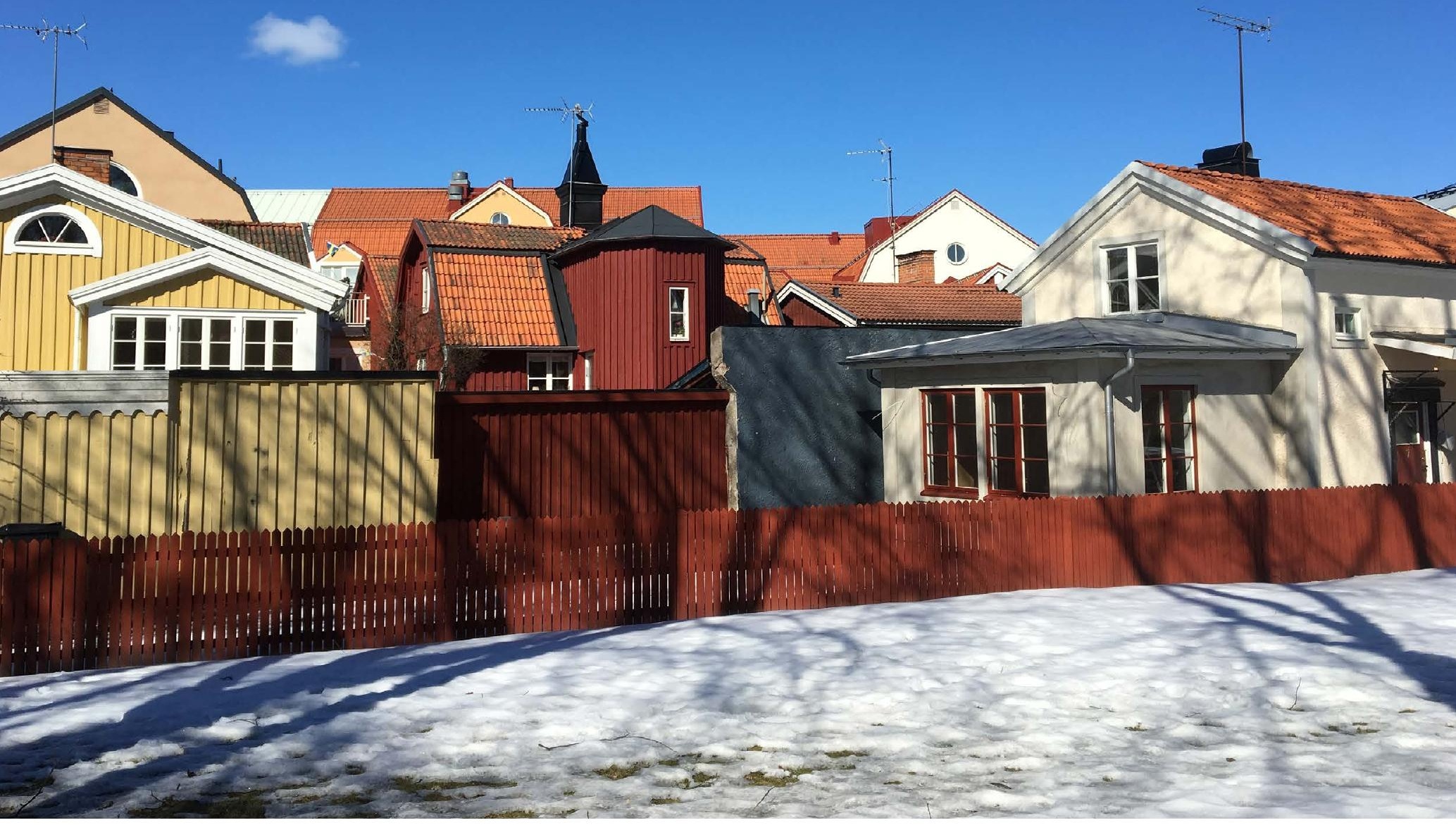

Small-scale wooden houses in central Västervik. Photo: Johannes Lidmo

to make the city centre into a living room for the city (Isotalus 2016, 6), and to increase the possibilities for branding the city through stronger profiling, stronger urban culture and renovated commercial spaces. The city centre needs a strong narrative, according to the development plan, and a structure without back yards or shadow spaces (Isotalus 2016, 22). Thus, the city centre development is both an image project and a planning project. However, a major challenge is the lack of housing in the city centre; apartment housing in particular (Isotalus 2016). The city is prepared for local debate about plans for new housing in the centre, since there are groups in Kokkola that consider this an unsuitable addition to the existing built environment.12 The strategy to densify has been on the agenda for the past year or so, according to the interviewees. It has emerged along with questioning of the out- ward growth and sprawl of the city, and also from the belief that consumer preferences are changing. A new generation of policymakers and politicians in the city hall and the merging of municipalities in 2009 have also contributed to changes in planning strategy.

Just as with cultural heritage, a railway can, in addition to being a physical barrier to development, also be an administrative barrier as a responsibility of the state. VR, the Finnish state-owned railway company is responsible for the railway, and any development near the station must be done in close collaboration with it. This adds complexity to urban development projects.

The main location for densification is within the administrative border of the city centre (see Figure 4). This map also shows the railway cutting through the city. The planned new district is south of the railway.

12 Source: Interview 5, see appendix. 


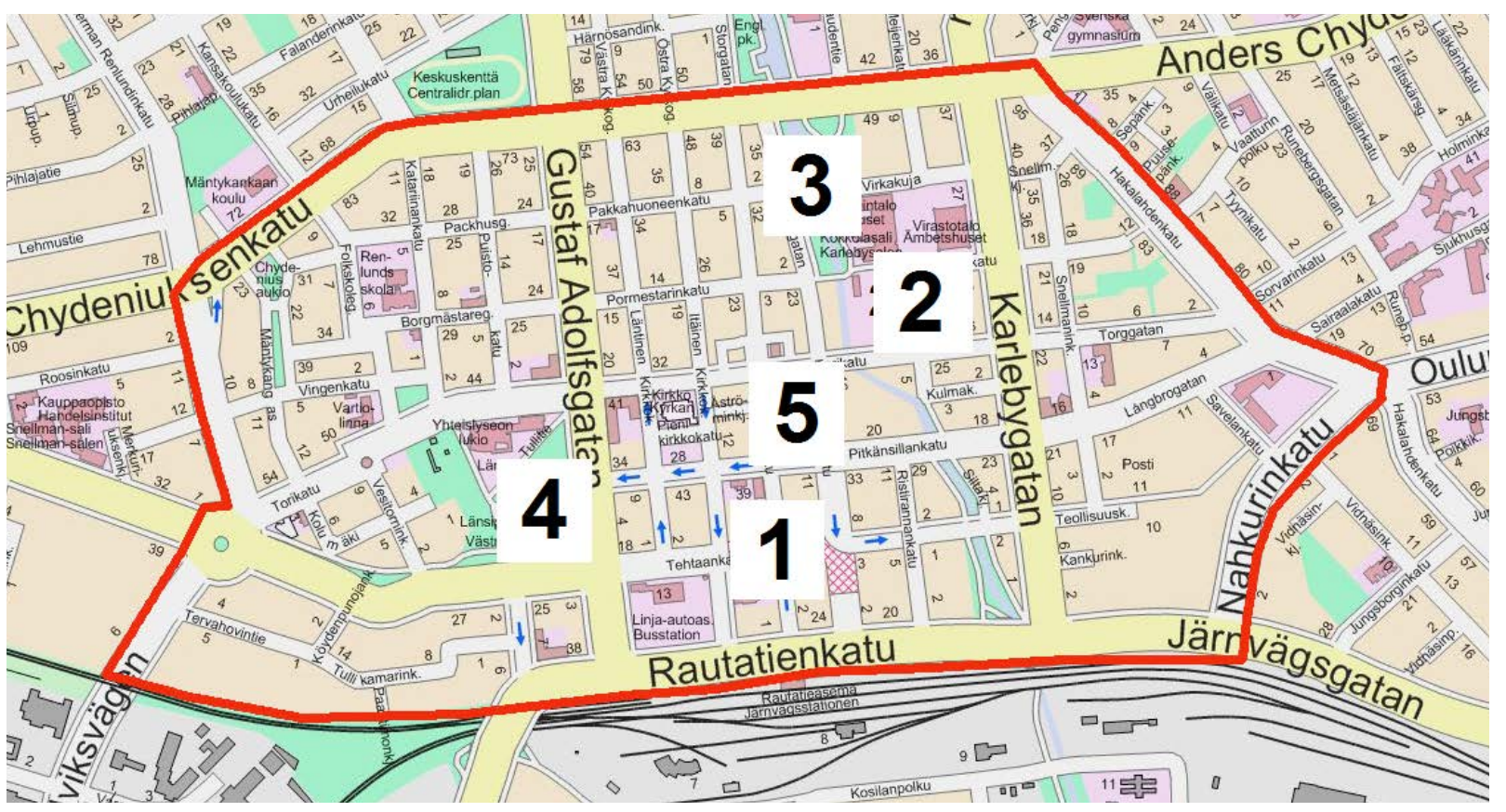

Figure 4: The defined city centre of Kokkola is inside the red line. The map also shows the important public spaces in the city centre, according to interviews and observations. 1: Pedestrian zone in the city centre and the small stage; 2: Market square; 3: Green area along the small river; 4: The public park Västra parken/Länsipuisto; 5: The public park Chydeniusparken/Chydeniuksen puisto. Edited map, based on map from Karleby stad (2015, 7).

In the Swedish city of Västervik, development is creating up to ten new apartments "here and there" in the city centre: mainly just outside the most central zone of the city. Here, city centre development is less about housing and densification, and more about actor collaboration, improved public spaces and preserving and making good use of the traditional small-town character. About one kilometre from the city centre there are more opportunities for new housing development, but on a rather small scale. Densification is a planning strategy according to the comprehensive plan for the whole municipality (Västervik kommun 2014), but not specifically for the centre of Västervik. Compared to the other examples, the city is hesitant about densification with new housing and aware of the complexity of implementing such a strategy: interviewees mentioned issues such as parking needs, commuting patterns and the structure of services in the city. In this region, many people commute, something that generates both car traffic and the need for car access to services, as well as housing demand near the railway station. Despite this, Västervik was awarded the city centre of the year 2017 by the association Svenska stadskärnor ("City centres of Sweden"). This award, however, is oriented more towards criteria such as actor collaboration and business development.
Mariehamn, in Åland, has a new plan (Mariehamns stad 2016) that intends to "widen the centre" by densifying and expanding it with both housing and commercial activities. Mariehamn city centre is considered to be deserted or even dead, in terms of both people and activities, as a result of competition from an external shopping centre. ${ }^{13}$ The preface to the plan for the centre states that external shopping centres are competitors to the city centre that it cannot currently handle. For Mariehamn, the alternative to the redevelopment of public space is simply to accept that the city centre will be more of a staged setting than a real centre (Mariehamns stad 2016). The current planning proposal is primarily about the attractiveness of the city centre. There are arguments about increasing housing and about the sustainability of Mariehamn, but the main intention of the planning proposal is to attract people to the commercial and public spaces of the city centre.

The starting point for the planning proposal is to create a compact and functionally mixed city that is economically, environmentally and socially sustainable (Mariehamns stad 2016, 8). Densification of housing is emphasized, in order 


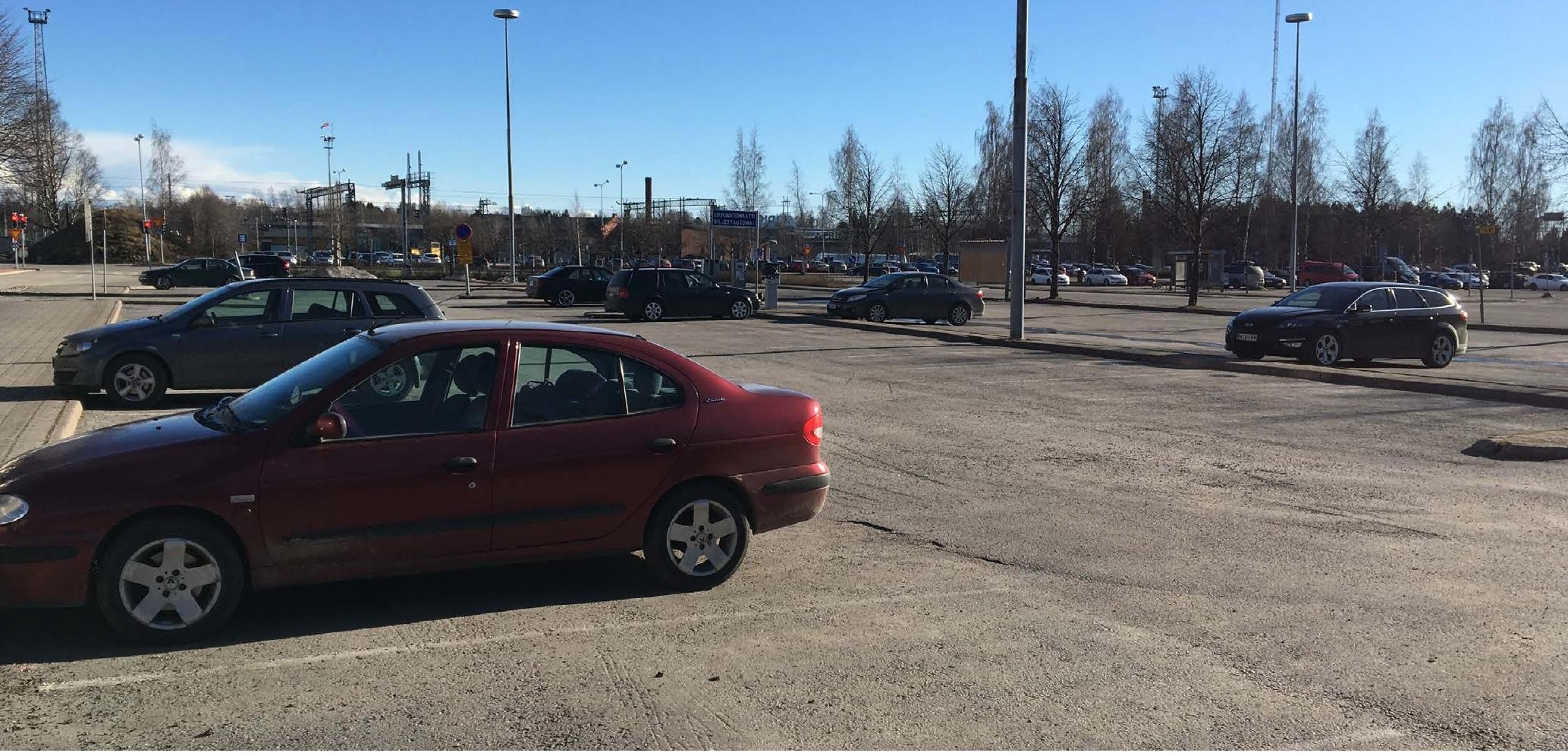

The central square Järnvägstorget in Kokkola that today primarily is a parking lot will be developed with housing. Photo: Johannes Lidmo

to transform the city centre from a garden city to a compact city, and to make it lively. The plan envisages 1,200 new residents in the centre, compared to the 420 that live there today (Mariehamns stad 2016). However, the plan also acknowledges the importance of consideration for the existing character of the city, its small scale and garden city character, and particular buildings and locations.

The proposed densification will occur through infill along the streets and in existing courtyards (Mariehamns stad 2016, 14). The plan refers to Swedish examples like Gamla stan in Stockholm, and Visby, as safer, more dynamic and more varied than the existing garden city structure of Mariehamn. The planning proposal also addresses commercial spaces and business locations (Mariehamns stad 2016). The plan specifically mentions the competition that cities suffer from web shopping, but also the potential of services such as hairdressers, dentists, fitness centres, etc. that require an actual and accessible location. The total commercial space in Mariehamn does not need to be increased, according to the plan, but rather redistributed. Ground-floor spaces can be used better, and meeting places for young people are needed. Office space does not have to be on the ground floor but does need convenient parking.

Mosfellsbær in Iceland is a Nordic city in a different situation to the others in regard to densification. It has long served as a suburb to
Reykjavík, but it is also a small city. According to the interviewees, the centre provides only very few commercial functions - shops, parking spaces, a few restaurants, grocery shops and gas stations. The municipality now sees the need to add housing to the city centre to add more life. The planners also expressed the desire of the municipality to improve the design of the centre:

"The centre as it is today is not a particularly attractive place to see sights, experience things or spend time. Now, it is rather just a place to get goods and services. But that is part of why we are changing the planning, to make the centre more attractive. Before the financial crash of 20082009, the square was rebuilt, but then very little happened in the years after, mainly because of the financial difficulties. It is just recently that work in the area has begun again. Right now, there is not much life in the area; there is a lot of concrete and not enough flowers and greenery. The plans for the area in the centre and around the square however propose that a new church and a cultural centre will be built. This, along with new residential buildings, is conceived as an attempt to create new places and make the centre more attractive and filling it with more life."14 


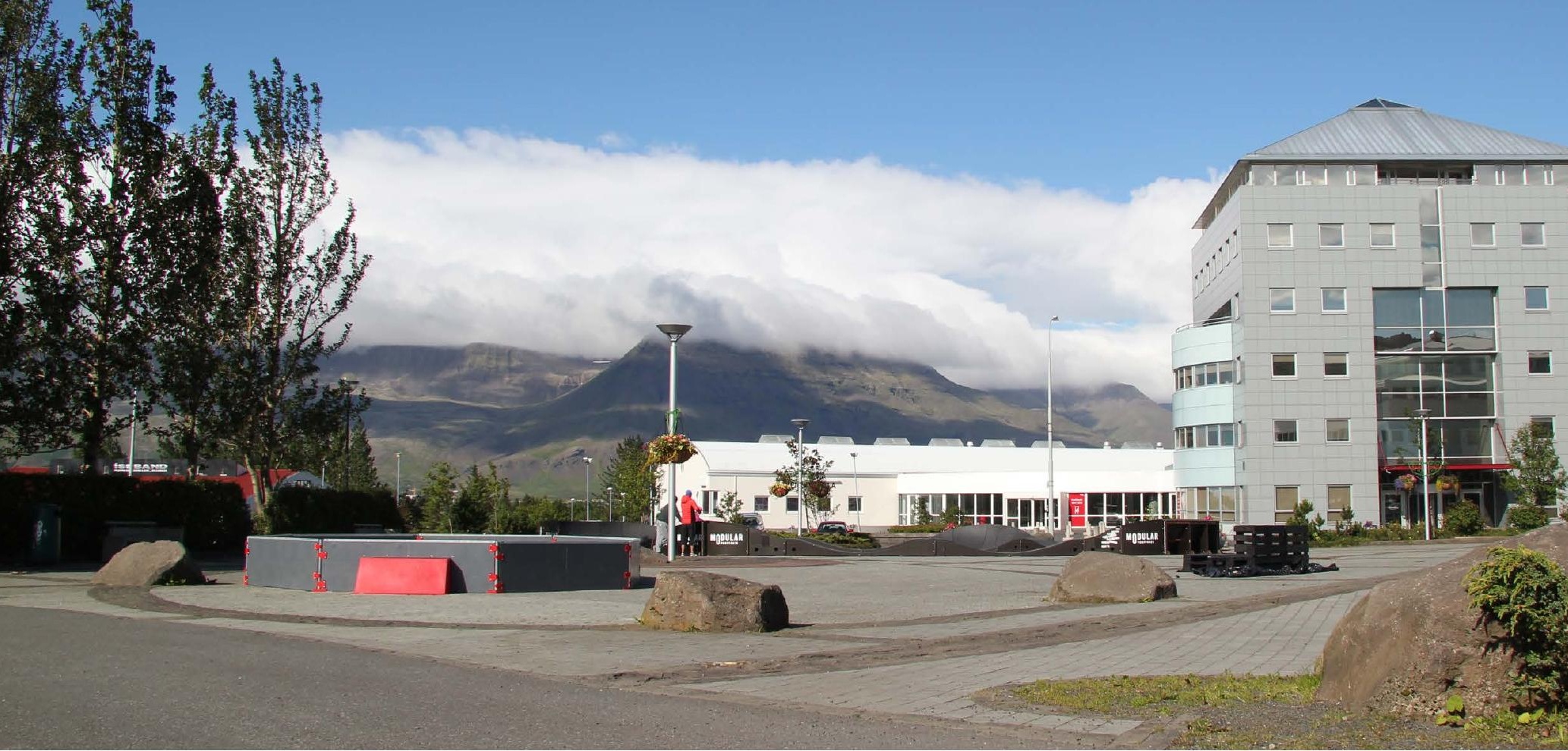

The central square in Mosfellsbær. Photo: Ágúst Bogason

The aim is to create a more compact city, mixing commercial spaces with new housing. The interviewees also referred to the fast population growth in Mosfellsbær municipality, creating demand for more housing:

"In the last four decades, the population of Mosfellsbær has changed from 2,000 people to 11,000. In fact, you might say that we have undergone change and developed from a rather sparse and rural municipality into a prosperous small town. In the last year, [2017] Mosfellsbær was the fastestgrowing municipality in Iceland, with around $8 \%$ population growth."16

Mosfellsbær has been referred to as "countryside within the city". Proximity to nature and outdoor activities has been a strong reason for settling here.

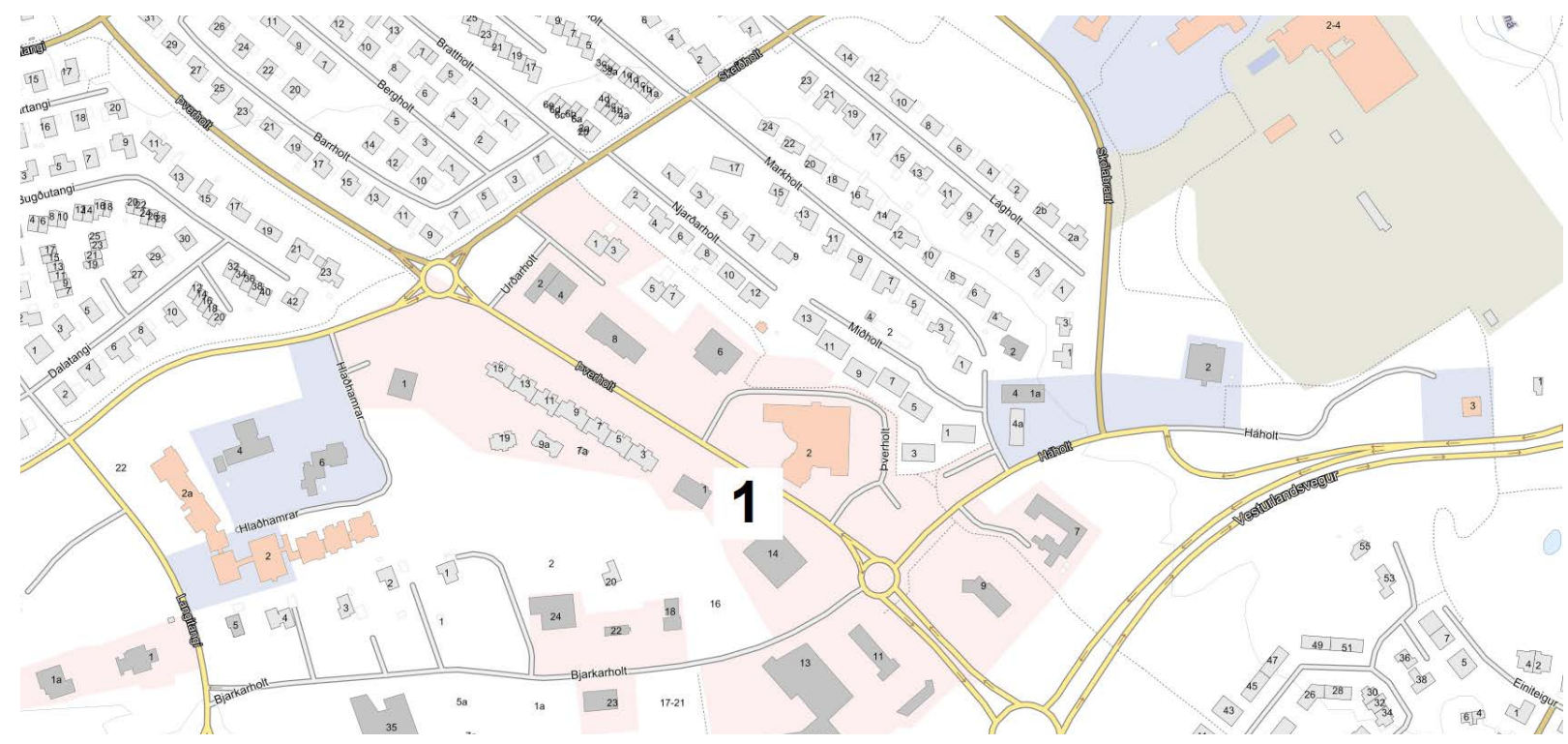

Figure 5: Map over central Mosfellsbær and its important public spaces. 1: The square. Edited map, based on map from Mosfellsbær Map Service. ${ }^{15}$ 


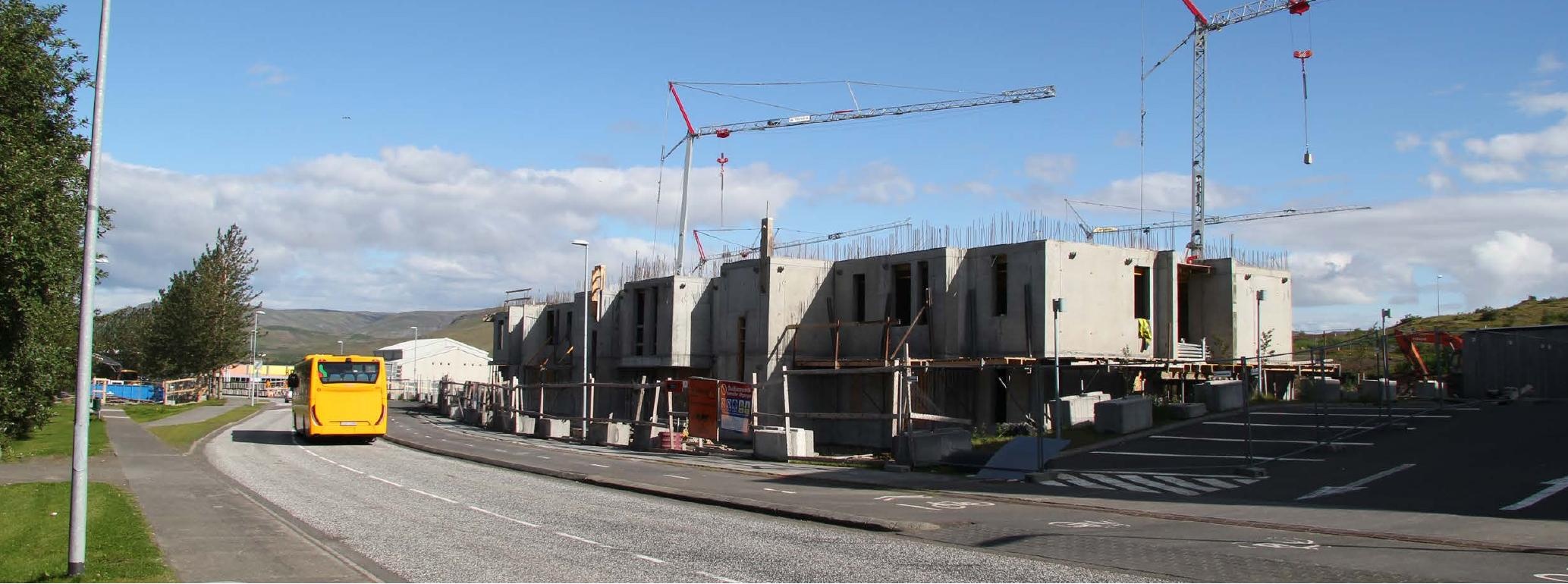

The ongoing urbanisation of Mosfellsbær. Photo: Ágúst Bogason

It has not previously been considered desirable to live in or near the centre of Mosfellsbær, but the current ambition is to change this image and attract new kinds of people. At the time of writing, there were 250 apartments under construction in the centre. Moreover, there is political unity on the issue:

"This densification is a political policy that has been supported by different parties in Mosfellsbær's municipal council, so we will be seeing an increase in the number of inhabitants around the centre with further residential construction in the area." ${ }^{17}$

In the Norwegian city of Bodø, developing the compact city and a strong city centre has been a long-term objective in several municipal plans (Bodø Kommune 2014). The strategies to achieve this are ensuring that a major share of the growth takes place in the so-called urban development area ("byutviklingsområde") and facilitating highquality housing projects, good urban areas and green structures in the city centre and in nearby districts (Bodø Kommune 2014, 26). When the planners in Bodø were interviewed about the reasons for densification, the main arguments involved environmental issues such as space for new residents, reduced transportation needs and avoidance of construction on undeveloped land. The current Norwegian national goal to reduce the use of private cars contributes to this thinking. ${ }^{18}$ Another reason to densify is to encourage social

17 Our translation. Source: Interview 6, see appendix. 18 The zero growth goal for private car use was a part of the government's climate agreement in 2012, see more here: https://www.regjeringen.no/no/tema/transport-og-kommunikasjon/kollektivtransport/belonningsordningen-bymiljoavtaler-og-byvekstavtaler/id2571977/ interaction. The belief is that a compact structure will increase walkability, and the use of public spaces - for socializing, urban gardening etc.

Even though the compact city has been an urban development ideal for quite some time, housing construction in the centre of Bodø was restricted until 2014, when the current municipal plan was adopted. Since then, several housing projects have started, and a few central buildings have also been demolished to make space for more compact structures, including high-rise buildings. The planning of a new district, in a former airport area just outside Bodø city centre, cannot be seen as densification of the city core, but it will nevertheless significantly change urban life in the city in the coming decades. The area is envisioned as a compact and mixed neighbourhood with up to 15,000 dwellings. It is planned that this area, and not the densified city centre, will host the majority of the population growth in Bodø for the next 50 years.

\section{Urbanizing the city core with new housing}

As mentioned in the previous section, adding housing to the city centre is a common strategy in the search for urbanity. In Nordic cities, the city centre is often dominated by commercial spaces, making it empty after business hours. Centrally located housing is therefore a common strategy in making the city centre livelier, as well as more compact and functionally mixed.

In Sorø, the interviewees considered city centre development a challenge, because geographical preconditions really limit outward growth. Another challenge is the housing market. The municipality is dominated by large single-family housing, making it difficult for both the young and the old 
to settle there. Frederiksberg, where the majority of new housing development is taking place, has been more of a commercial and service centre with the railway, a school and small shops. Even though spatially separated from Sorø centre, it is considered a part of the city. In essence, the challenge is dual: the city needs to both handle the limitations to growth in the city centre, and yet provide for a functional mix there while also creating appropriate new development in Frederiksberg.

Both Sorø and Kokkola see a challenge in creating opportunities for the young and the elderly to live centrally, in apartments instead of large single-family housing. The interviewees in Kokkola admit that families with children are not attracted to the city centre. One reason is that historically, inhabitants could very easily buy land for a house in Kokkola. Several single-family housing areas were planned and built by the city until about a decade ago. At that time, the city sold or rented out 100-120 lots each year, but now this figure is only around 30. The prior generous policy resulted in a sprawling city, but today the ambition of the city is to reverse this trend by building apartment housing in central locations and by concentrating services. According to the interviewees, the arguments behind this are mainly related to both financial and land resource efficiency.

Among the cities in this study, Mariehamn most clearly expressed challenges relating to both commerce and to housing in the city centre. External shopping centres are threatening the shops in the city, spaces are being turned into offices, and there are too few central housing opportunities. The city would like more housing and residents in the centre, anticipating that it would bring life into a city that is nearly "dead", especially in the evenings. ${ }^{20}$ The interviewees in Mariehamn expressed hope that the trend seen in other cities, with families staying in or moving to the central city, will also come to their city. The city owns very little land in the centre which makes it dependent on private

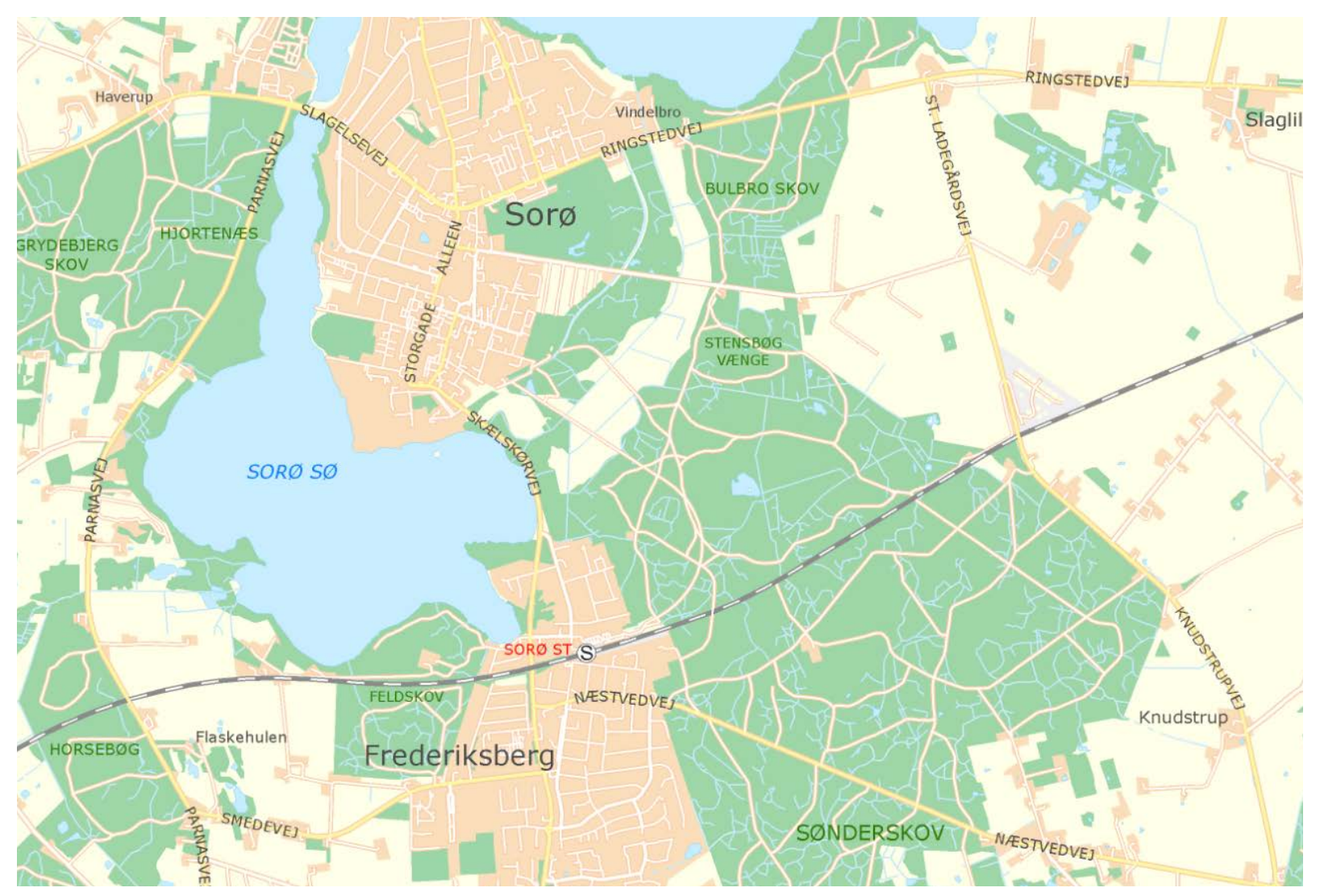

Figure 6: Map of Sorø showing the limitations in the surrounding landscape, and the division between Sorø and Frederiksberg, which hosts the train connection. Source: Sorø Map Service. ${ }^{19}$ 
actors. Although there is available development land, land owners are waiting for times with better revenues. In addition, Mariehamn is experiencing competition from the neighbouring municipalities, where there is both available land and attractive single-family housing.

In Mosfellsbær, the situation is somewhat different. Rapid population growth since 2000 has generated a great deal of new housing, mainly concentrated in two new neighbourhoods outside the defined city centre. Our interviewees felt that the central area would become more attractive in the coming years, and as mentioned above, 250 apartments are currently under construction. Among the target groups are young people entering the housing market and younger families. In addition, others are expected to sell their house in the outer areas and move into the attractive city centre.

Bodø is a large city in relation to the others studied and is expecting to grow considerably in the coming decades. In spatial planning, key objectives include dealing with the negative consequences of car traffic, increasing human interaction and limiting land take. Currently, the city centre is being densified through apartment buildings and, according to one of our interviewees, these new dwellings are primarily attractive to young or elderly people. Families are still - just as in Sorø and Kokkola - attracted to detached housing outside the central parts of the city. Despite the fact that around 800 new dwellings are under construction (at the time of writing), according to a forecast there is a need for another 350-400 dwellings every year within the defined urban development area, which includes the city centre. In total, about 2,200 dwellings (including 1,600 in the commercial core) are planned in the coming years. ${ }^{21}$ According to our interviewees, the number of residents in the commercial city core in Bodø will already double in 2019-2020.

\begin{tabular}{|c|c|}
\hline & $\begin{array}{l}\text { Quantification of new } \\
\text { housing development in the } \\
\text { city cores }\end{array}$ \\
\hline Mosfellsbær & 250 dwellings \\
\hline Sorø & $\sim 20$ dwellings \\
\hline Bodø & $\begin{array}{l}-2,200 \text { dwellings (of which } \\
1,600 \text { in the commercial city } \\
\text { core) } \\
\sim 800 \text { dwellings are already } \\
\text { under construction in the } \\
\text { commercial city core. }\end{array}$ \\
\hline Västervik & Some here and there \\
\hline Kokkola & $\begin{array}{l}\text { The ambition is to increase } \\
\text { the number of residents } \\
\text { from } 3,900 \text { to } 6,000 \text { within } \\
1-5 \text { years }\end{array}$ \\
\hline Mariehamn & $\sim 1,200$ dwellings \\
\hline
\end{tabular}

Based on interviews and planning documents.

\section{Governing city centre development}

In this section, we examine city centre development from a governance perspective, i.e. through the actor collaborations that are important for getting things done in cities (Edelenbos \& Van Dijk 2017). Who is involved, how are planning policies formalized, and what are the governance barriers to development? What are the particularities of urban governance in small and medium-sized cities?

\section{Governing small cities}

"Small cities are typical in a quantitative sense, and theorists have been too dazzled by the spectacular urbanism of big cities to notice them. They are unique in that the way they 'do' cityness is distinctive, while still recognizably urban." (Bell \& Jayne 2009, 695)

"What the larger cities do, that's what the small cities do subsequently. That sums up more or less what's going on." 22

The size of a city can be indicative of both planning challenges and opportunities. The category of cities in this study - small and medium sized - is broad,

22 Our translation. Source: Interview 5, see appendix 
making the self-perception of the city important. For the actors involved, does their city seem small, and in what way does this city image influence urban development?

\begin{tabular}{|c|c|}
\hline & $\begin{array}{l}\text { Interviewees' perceptions of } \\
\text { their city. }\end{array}$ \\
\hline Bodø & $\begin{array}{l}\text { A small "large city" ("en liten } \\
\text { storby") }\end{array}$ \\
\hline Kokkola & $\begin{array}{l}\text { Too small to be a big city, but } \\
\text { too big to be a small city }\end{array}$ \\
\hline Mariehamn & $\begin{array}{l}\text { Small city with ambitions of a } \\
\text { metropolis }\end{array}$ \\
\hline Mosfellsbær & $\begin{array}{l}\text { Large municipality on an } \\
\text { Icelandic scale }\end{array}$ \\
\hline Sorø & Small city \\
\hline Västervik & Medium-sized city \\
\hline
\end{tabular}

The urban settlements in our study have quite different population figures (see Table 1). Most of the people we interviewed were uncertain of the population size of their urban settlement, since it is the municipality as a whole that is their main focus in planning and development. Some interviewees followed official categorizations when defining the size. However, these definitions vary across the Nordic Region (Smas 2018). Perceptions of size are therefore particularly interesting. Even though most interviewees are aware of their relative smallness, they also emphasize relative "bigness", as shown in Table 3.

Potentially, it is easier to co-ordinate issues and collaborate internally in a small or mediumsized city. However, both Västervik and Kokkola have previously had difficulties in internally co-ordinating issues of urban development. In Kokkola, it used to be the case that different public administrations would do almost the same work, in parallel. Nowadays, they communicate better, according to the interviewees. The development of the city centre of Kokkola today is an obvious example of internal co-ordination. The planning office, the business development actors and the city centre development office all co-ordinate their efforts.

In Västervik, improved internal co-ordination has been a very practical matter related to the location of the different public administration departments. Spatial planners having their desks next to traffic planners, park administration staff, etc. makes communication much easier, and makes colleagues open to broader involvement in a variety of issues. In Mariehamn, all actors based in the city centre know of each other, according to our interviewees. However, this does not mean that collaboration automatically becomes easy. The commercial actors, the property owners and the municipality have been working on improving their co-ordination and collaboration: a process that, at the time of writing, is ongoing.

Small or medium-sized cities can of course be considered big, depending on where one looks for comparisons. In Västervik, one planner felt that the municipality was big enough to work with a broad range of planning issues. In small cities, the risk is that one specific planning issue receives all the attention and focus of the planning office. The interviewed planners in Sorø had a somewhat different view: in a small city, they argued, there are no large urban development projects; instead, the city tends to work only with small planning projects. However, the development of a Masterplan for Sorø (see Sorø Kommune 2012), has been important for the planners, giving them a view that overarches all districts and sees the whole city as a single, rather large project.

\section{Lessons learned from making plans and analyses}

The cities reviewed in this report were selected because they had already identified a need to improve their city centres. In the process of addressing these needs, the cities have produced plans and strategies addressing their specific challenges in somewhat different ways. They act in accordance with their country's national legislation and their national and regional context. In Västervik, the major challenge has been the threat from external shopping centres and the need to recreate a lively city centre. This has resulted in new collaborations and the use of new planning tools, such as a plan specifically addressing the passages through the city ("Stråkanalys"). This plan played a key role in understanding the role and importance of the locations of different types of retail outlets and businesses. According to the interviewees, the property owners have had (and still have) major responsibility for implementation of the actions recommended in the plan. New 


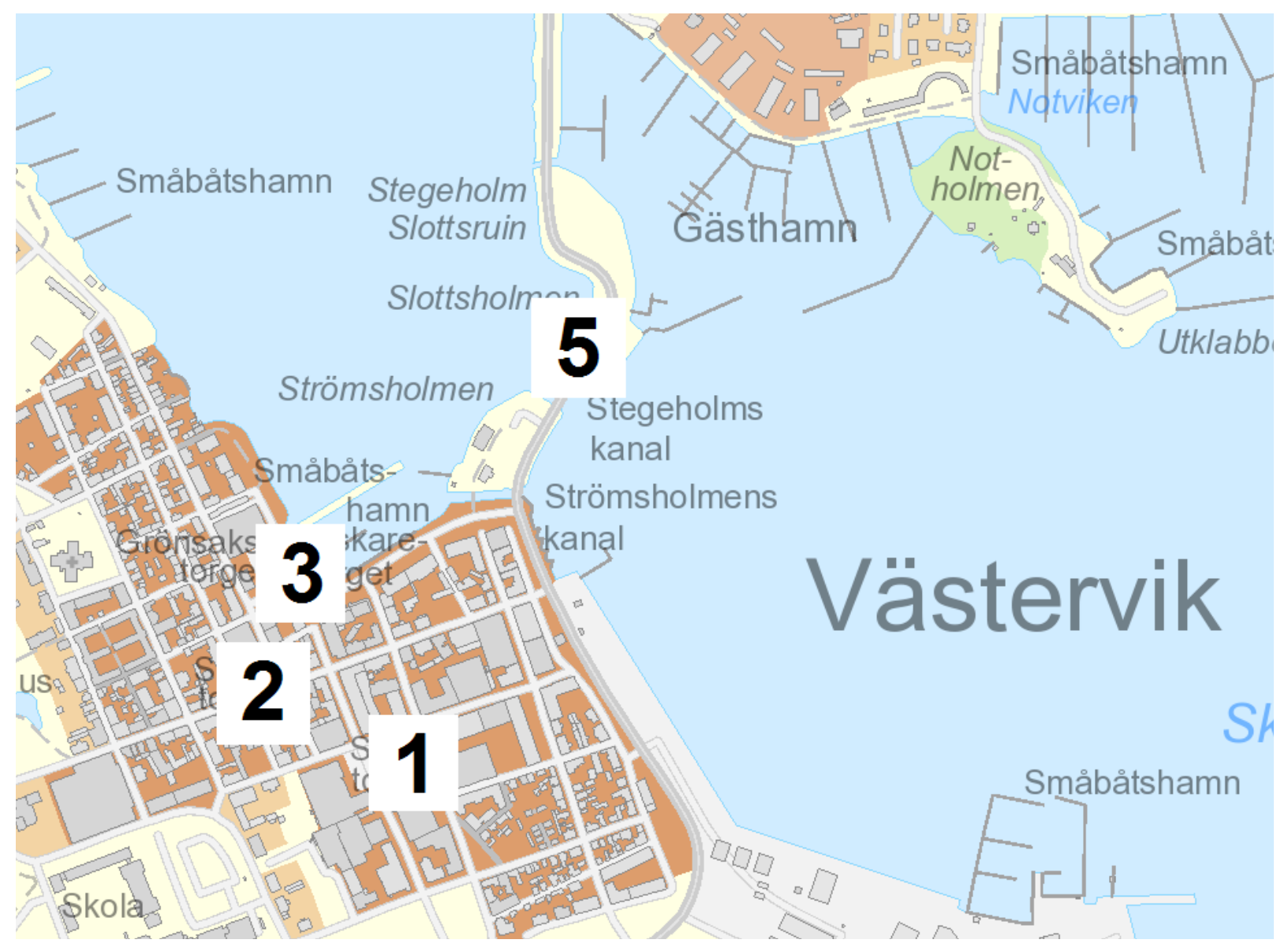

Figure 7: Map of Västervik city centre and its important public spaces according to interviews and observations.

1: The square Spötorget; 2: Main square; 3: The squares Fiskaretorget and Grönsakstorget; 4: City park;

5: The waterfront promenade. Source: Edited map, based on map from Västervik Map Service. ${ }^{23}$

guidelines for property owners on what to do when they have available premises (Västervik Citysamverkan 2017) have meant that some types of businesses are prioritized at some locations and have facilitated the relocation of shops in the city centre. While these guidelines have played a crucial role to date, key actors have nevertheless continued to draw up action plans related to their own specific priorities. One planner emphasized the importance of prioritizing measures that are cheaper and faster. In doing so, it is easier to convince others about the process and bring them on board.

In Kokkola, a specific development programme for the city centre was published in 2016 (Isotalus 2016). The programme was based on interviews with inhabitants, local actors and local planners. It was elaborated as a response to concerns re-

23 Source: https://www.vastervik.se/Kommun-och-politik/ Kartor-och-geografisk-information-GIS/kartor/ garding the viability of the city centre. The focus was to strengthen the centre from a city life and business perspective; it included both visions and objectives (of which some are spatially oriented) but, more importantly, concrete actions on how to achieve the desired development were recommended. These detailed a broad range of measures and the responsible actors. For instance, one action was to reconstruct a road whilst another was to implement a lighting plan (see more in Isotalus 2016, 36-39). As in Västervik, the actions were identified and listed, which facilitated their implementation. One interviewee explicitly highlighted the usefulness of the listing of actions. According to her, plans and programmes easily become just paper tigers, i.e. they mean nothing concrete in practice. In this programme, the listed actions are quite concrete. Another lesson learned from the programme so far, according to our interviewees, is to list only actions that are realistic within the time frame. 
In Sorø municipality, there is also a specific development plan for the city of Sorø (Sorø Kommune 2012). The main role of this "master plan" has been to formulate spatial objectives and to create an overarching view of the desired long-term spatial development. According to the interviewed planners, this document has been important as a support to strategic actions in the city centre. Even though the planners reported challenges in implementation, such as changing political support and lack of funding, the master plan has played an important role in ongoing development, for example in the central cultural district, the Kulturfirkanten. In parallel to the master plan, detailed plans were developed proposing concrete actions and examples. One of these concrete actions is development of the space called Biblioteksgården, the inner yard outside the library, shown in Figure 8.

In Mariehamn, the process has developed in a similar manner as in Västervik, with the aim being to improve and enhance the liveliness in the city centre through a collaboration between the city and the business sector. The process began in 2011, when funding from the European Regional Development Fund was approved for a project with the purpose of making the city centre more viable. A project consortium consisting of the Åland Chamber of commerce, Mariehamn municipality and other actors based in the city centre was formed. The focus was initially to attract larger retail companies to the city centre. This focus had to change slightly when the shopping centre Maxinge was established only about $4 \mathrm{~km}$ outside of Mariehamn city centre in the municipality of Jomala. It was necessary to change strategy in response to this competition. Therefore, a major outcome of the project was instead the commencement of ongoing dialogue between the various actors in the city centre.

Subsequently, an action plan came out of the project. It included an analysis of the passages in the city (similar to the so-called "Stråkanalys" in Västervik, mentioned above) and other underlying analyses (Mariehamns stad et al. 2012). This action plan proposed some immediate measures that had to be visible as soon as possible (Mariehamns stad et al. 2012, 58). One was to prolong opening hours in the shops, and another was to improve the advertisements in the streets. Perhaps more relevant from a governance perspective was the introduction of a formal collaboration platform, today known as City Mariehamn. The interviewees felt that the current planning work for the city centre (Mariehamns stad 2016), including plans for housing, is a good example of what the collaboration has made possible through its regular input to the municipal planners. Nowadays, the organization City Mariehamn has a formal committee role in the Åland Chamber of Commerce.

Although this section has focused on examples of new planning, the significance of traditional

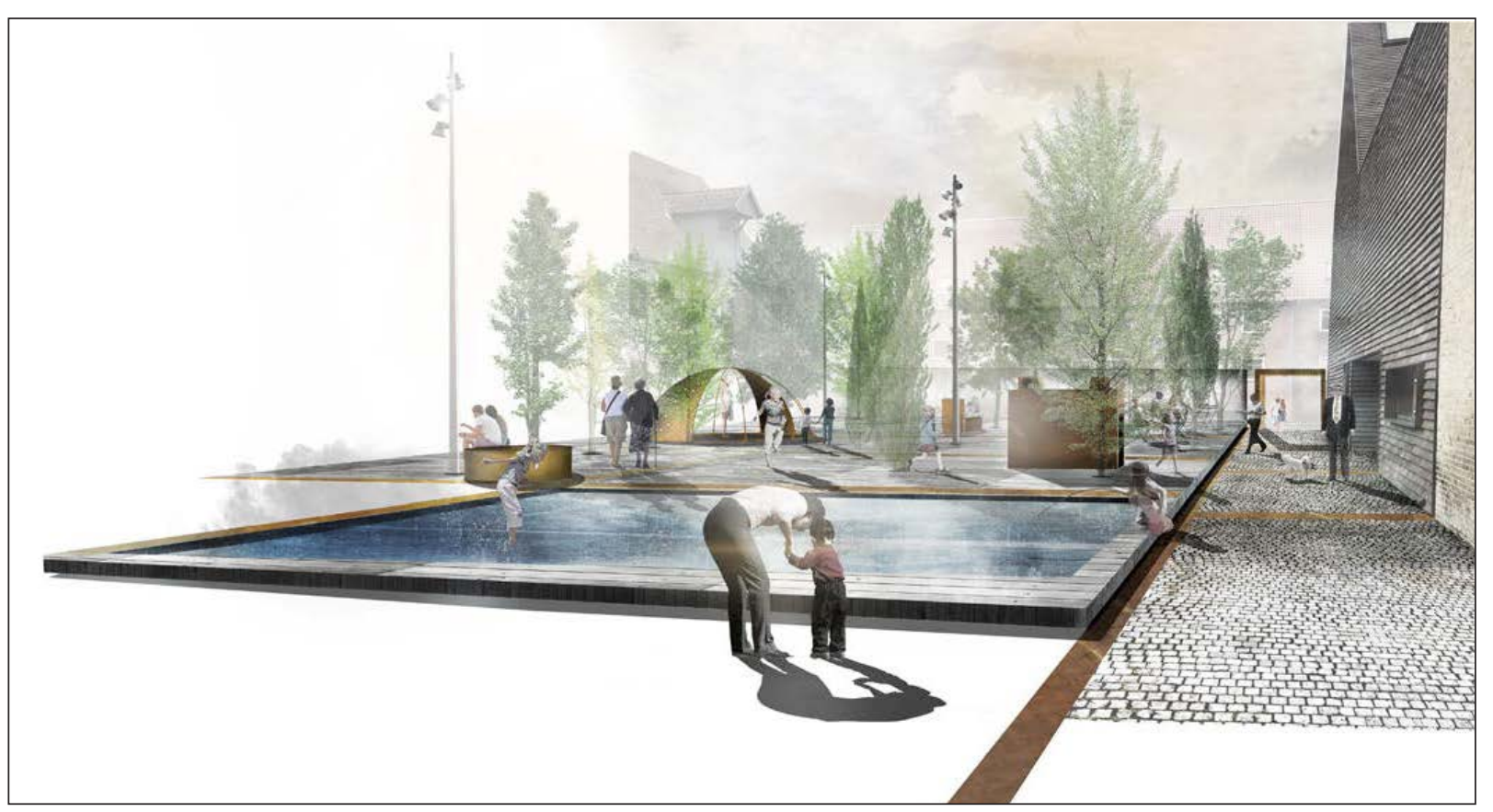

Figure 8: A view from the street Storgade of the proposed Biblioteksgården. Source: Sorø Kommune (2016, 22). 

between the local trade association, the property owners in Västervik, and the city emerged. Thus, Västervik Citysamverkan (Figure 9) was born, and is today co-ordinated by VF. Many of VF's projects are now funded by the city: for example, development and implementation of a tourism strategy for 2013-2020. The collaboration has never been completely formalized but is governed by agreements. This means that the collaborators act by their own power and legitimacy and take on initiatives in their respective arenas; initiatives that are strengthened by the collaboration. Both civil servants and politicians represent the municipality, demonstrating political support for the collaboration (above right).

Every year, a new operational plan is produced which sets a framework addressing the main priorities, and regular meetings are held over the year. Planners are often invited to present proposals and receive input at an early stage, according to one of the interviewed planners. The main outcome of the formalized collaboration is that issues relevant to the city centre are discussed on a regular basis with a mix of diverse actors. By going through Citysamverkan, with VF's co-ordination, the process of reaching out to relevant local actors is smooth and

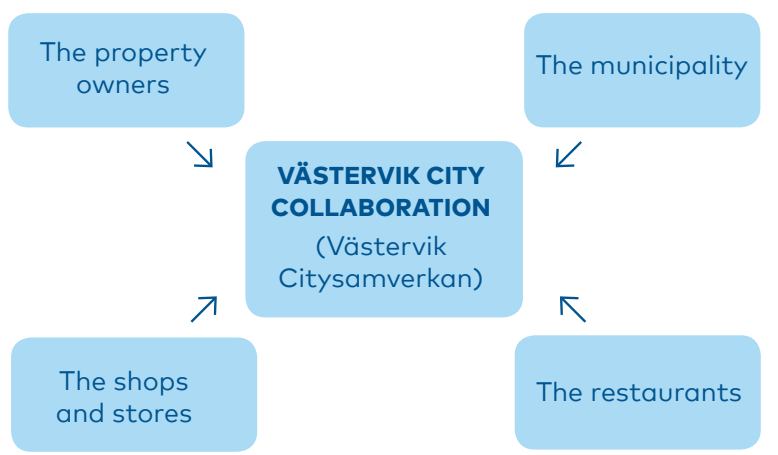

Figure 9: All main actors involved in Västervik Citysamverkan. Source: Own figure based on interview no. 1.

has, according to one interviewee, facilitated local development. The collaboration revolves to a substantial extent around shopping and trade-related issues but has turned into an important platform for municipal civil servants by enabling open dialogue on a regular basis.

The experience of Mariehamn is very similar that of Västervik. One notable outcome has been an agreed Street programme for Mariehamn (Mariehamns stad et al. 2014). Other results in the Ålandic city concern events, marketing and furniture and flowers in the city. However, there are also

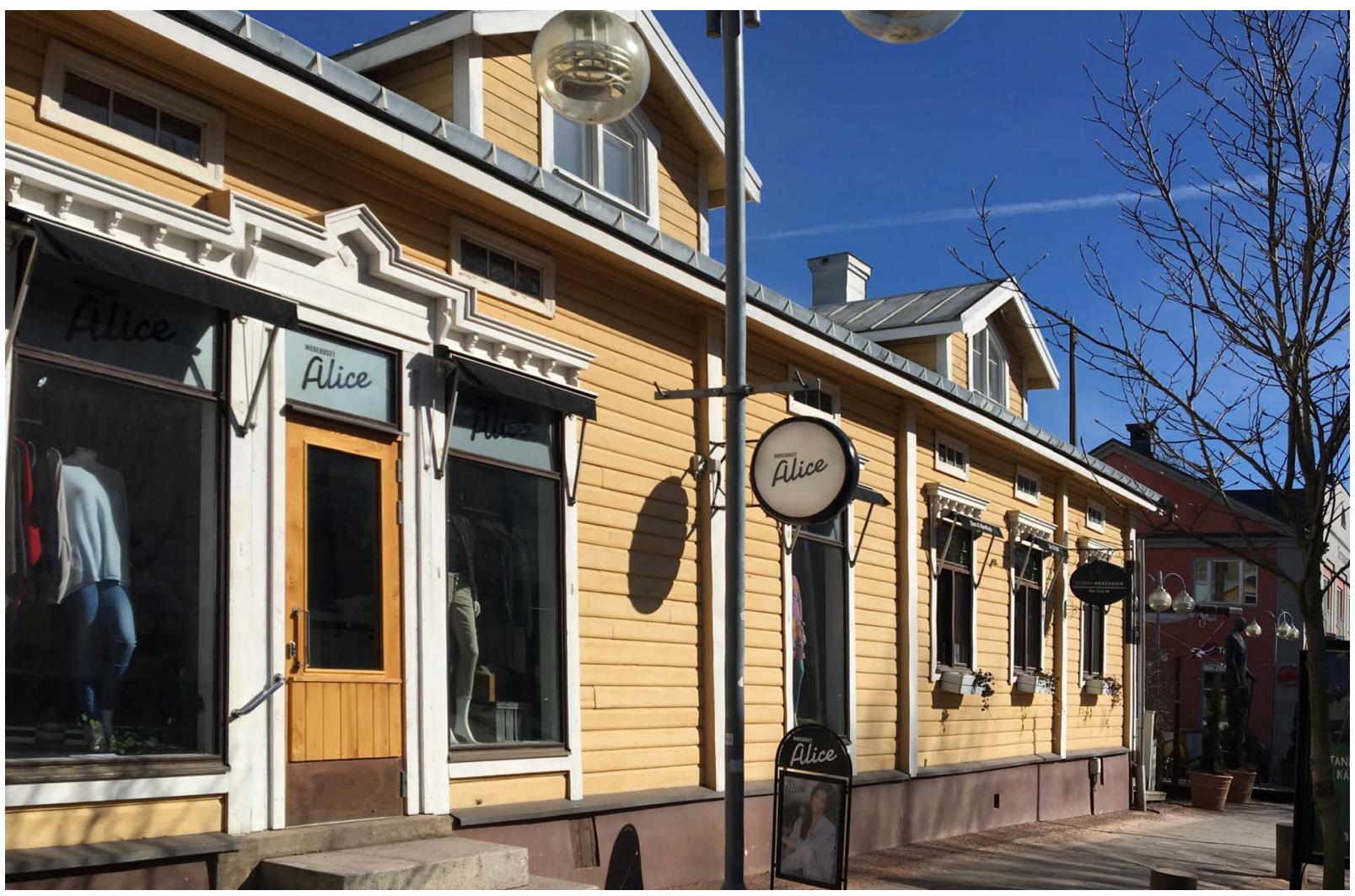

Small-scale shopping in Mariehamn city centre. Photo: Johannes Lidmo 
challenges to the collaboration. Even though property owners, the business sector and city officials are all engaged, they are relatively small actors who need to prioritize their own agendas, sometimes to the disadvantage of the overall agenda of City Mariehamn. ${ }^{24}$ Another challenge is to find ways to interact with those who do not want to be engaged members of City Mariehamn.

\section{Learning through networking}

Smaller cities must collaborate with, and seek inspiration from, other cities with similar challenges and opportunities. We found two interesting examples of this strategy. First, in the Norwegian region of Nordland, an annual urban design seminar has been organized since 2010 (Nordland Fylkeskommune 2018). Prior to the first seminar in 2010, Bodø municipality had initiated contact with the region, asking for advice on how to manage its current urban issues and planning challenges, especially those related to urban and public spaces. From this, the annual Byromsseminariet was born with the ambition to mobilize thoughts on urban development. The seminar is action-oriented, meaning that delegates work with concrete city planning challenges in a workshop format. In the seminar of 2010, a landscape architecture firm was procured to co-ordinate the workshop, and it resulted in a detailed analysis of Bodø city centre. According to the interviewed regional planner, points of detail, such as "this street is important" and "where to put bicycle lanes", were examined and resulted in urban design guidelines for Bodø city centre (Asplan Viak/Arkitekturverkstedet Oslo 2012). In other words, this is concrete city planning with input from the seminar participants, i.e. representatives from the entire region. One interviewee described the seminar as an important arena for learning from each other: the individual cities gain perspectives from outsiders on their specific problems.

Secondly, Mosfellsbær is currently involved in the Nordic project Attractive Nordic towns and regions together with a number of small Nordic cities. The project is led by the Norwegian Ministry of Local Government and Modernisation. It aims to identify indicators for attractiveness and to "prepare a joint Nordic strategy for how towns and their surrounding areas can become more attractive through the development of vibrant and inclusive urban environments that are economically, environmentally and socially sustainable" (Kommunal- og moderniseringsdepartementet 2018). At time of writing, it was too early to determine how involvement in this project will affect Mosfellsbær's city centre development, but the project illustrates how this small city is searching for new ways of making its city centre (and city as a whole) more attractive. 


\section{Conclusions and lessons learned}

A number of experiences relating to city centre development in the Nordic Region have been reported here. The experiences illustrate the many parallel and related challenges that small and mediumsized cities face, with varying degrees of severity. The central part of a city is a limited space for which there are extremely high expectations. Appropriate development requires co-operation across sectors and actors, recognition of its regional role, and investment in both the centre and the periphery to create a balance that attracts residents, visitors and consumers. This is a huge challenge for smaller cities. To conclude we want to mention a few lessons learned from this study:

This study was interested in what the city centre is, or should be, when it no longer has an obvious role. Instead of finding the new role for city centres, our investigations have led us to conclude that there is no essence to be found. It is instead important to understand the city centre as dynamic and constantly changing. Our studies indicate that the dominant idea today is that the centre should be a place for events and experiences rather than, for example, simply a public or political space. This belief makes centre development primarily about municipalities collaborating with real estate interests, business owners and event organizers on topics ranging from signage to large-scale new developments. The city centre is very clearly an arena for many different actors. Formalized cooperation bodies and continuous dialogue between the actors are considered as positive for development.

The focus on dynamism and collaboration suggests that centres should be flexible spaces able to adapt to trends in housing preference, external shopping and e-commerce. This flexibility is evident in strategies such as redistribution of office and shopping spaces for increased visibility and accessibility, and parallel investment in the city centre and external shopping centres, rather than seeing these as competitors.
The small city of Sorø suffers from limitations related to the existing built environment and the city's morphology, and to its location as a commuter city near Copenhagen. It is unable to densify or develop the city centre with new housing. Mosfellsbær is also a commuter city, but about to become a city more on its own terms through a strong population growth. It has had, in contrast to Sorø, a unique opportunity to build both housing and new spaces for businesses and services, and the development of a totally new centre is ongoing.

Even though there is a strong focus on commercial spaces, there are also public spaces of importance in smaller cities - parks, squares, waterfront promenades, etc. They can however be scarce, and therefore it is of great importance that they are safeguarded, open and used. We stress the importance of non-commercial public spaces to ensure that the city centre is not merely a commercial arena. Without diversity, the commercial arena also comes under pressure. Mariehamn, for example, described their central area as "dead". Bringing it back to life meant improving conditions for businesses. Kokkola and Bodø have instead focused strongly on making the city centre an attractive place to live, and hence to also reduce urban sprawl.

Densification in Nordic cities is often about developing new housing. Many city cores have historically been developed as, or turned into, purely commercial centres. Some, like Bodø, even had rules against building housing. At the same time, smaller towns and cities are not under the same pressures as big cities, and a densification project can involve only a few blocks or a small number of new dwellings. A strong impression from the investigated cities, when it comes to development of new housing, is that many of the planners rely on hope: a hope that the trend will change in smaller cities, and that people - not only the young and the elderly - will be attracted to living centrally, and 
in apartments instead of in single-family housing. However, the planners cannot yet see this occurring. This makes densification and enlargement of the central city more of a planning ideal, an expression of the urban norm, rather than a response to existing demand. Indeed, the studied cities are not all examples of core densification and the compact city being rolled out. Instead, in a few of the cities, densification is more obvious just outside of the city centre. In Bodø, a former airfield near the existing central area will become a whole new functionally mixed district. In Kokkola and Sorø, large new housing districts are being located near the railway. These are envisaged as independent urban districts in the city but are not in the immediate centre.

Finally, one issue that we were not actively investigating stood out in all our examples. At the core of the compact city ideal is the understanding that it reduces car dependency. Nevertheless, it was striking how decisive the car, car use and parking needs were in the cities. This remains an important factor in the understanding of the city centre and shapes the available strategies. New developments can reduce the space for parking, and car-free public spaces can reduce accessibility. Consequently, despite current moves to ban cars from city centres and government goals for zero growth in private car use, we saw examples of the necessity to continue to plan for cars, and to take car accessibility into account when planning housing, shopping etc. This left us wondering what it would take to change this, and what an actual urban development beyond the car would look like in the Nordic context.

Summing all this up points to the following:

Actor collaboration is central for city centre development

The city needs flexible spaces

Do not forget the non-commercial spaces when developing a lively city centre

- The compact city is a strong contemporary planning ideal, but it is not always a response to an existing demand

- Small and medium sized cities in the Nordic Region are still to a high degree planned with the car as a central actor. 


\section{References}

Asplan Viak/Arkitekturverkstedet Oslo. (2012). Formveileder for byrom i Bodø Sentrum. Bodø Kommune.

Bell, D. \& Jayne, M. (2009). Small cities? Towards a research agenda. International Journal of Urban and Regional Research, 33 (3), 683-699.

Bodø Kommune. (2014). Kommuneplan 2014 2026: Strategisk samfunnsdel Bodø 2030. Bodø Kommune.

Brenner, N. (2013). Theses on urbanization. Public Culture 25 (1) 85-114.

City Nord. (2018). Om City Nord. Available at: http://www.citynord.no/about. Accessed on 2 November 2018

Damsgaard, O. (2006). The role of urban areas in regional development - European and Nordic perspectives. Proceedings of the Nordic Working Group on Cities and Regions. Nordregio Working Paper 2006:4. Stockholm: Nordregio.

Edelenbos, J. \& Van Dijk. M.P. (2017). Introduction: Urban governance in the realm of complexity. In van Dijk, M.P., Edelenbos, J. \& van Rooijen, K. (Eds.) Urban governance in the realm of complexity. Practical Action Publishing. https://doi. org/10.3362/9781780449685.001

Erhvervsstyrelsen. (2017). Vejledning om detailhandelsplanlægning. København: Erhvervsstyrelsen.

Erhvervsstyrelsen. (2018). Detailhandel. Available at: https://planinfo.erhvervsstyrelsen.dk/ detailhandel. Accessed on 2 November 2018.

Florida, R. (2002). The Rise of the Creative Class and How It's Transforming Work, Leisure, Community and Everyday Life. New York: Basic Books.

Fredriksson, J. (2014). Konstruktionen av en stadskärna: Den postindustriella stadens rumsliga maktrelationer (Doctoral Thesis). Göteborg: Chalmers University of Technology.

Gehl, J. (1971). Livet mellem husene. København: Arkitektens forlag.

Gehl, J. (2010). Byer for mennesker. København: Bogværket.

Glaeser, E. (2011). Triumph of the City: How Our Greatest Invention Makes Us Richer, Smarter, Greener, Healthier, and Happier. New York: Penguin Press.
Isotalus, T. (2016). Ett centrum med många skikt: Utvecklingsprogrammet för Karleby stadscentrum. Karleby stad.

Jacobs, J. (1961). The Death and Life of Great American Cities. New York: Vintage.

Karleby stad. (2015). Generalplan för Karleby Innerstad: Program för deltagande och bedömning. Karleby stad.

Karleby stad. (2017). Karleby stads strategi 20182021: Karleby förnyas djärvt. Karleby stad.

Kommunal- og moderniseringsdepartementet. (2016). Byrom - en idéhåndbok. Hvordan utvikle byromsnettverk i byer og tettsteder. Idéer, strategier, eksempler. Kommunal-og moderniseringsdepartementet.

Kommunal- og moderniseringsdepartementet. (2018). Attractive Nordic towns and regions. Available at: https://www.regjeringen. no/no/tema/kommuner-og-regioner/by-og-stedsutvikling/attraktivebyer/engelskversjon-attractive-nordic-towns-and-regions/ id2570494/. Accessed on 2 November 2018.

Mariehamns stad. (2016). Utkast till

Delgeneralplan för Mariehamns centrum. Mariehamns stad.

Mariehamns stad, Ålands Näringsliv, \& Studioö. (2014). Gatuprogram för Mariehamn. Mariehamns stad.

Mariehamns stad, Ålands Näringsliv, Backemar Consulting, \& Janne Sandahl Consulting AB. (2012). Vision \& underlag till Handlingsprogram 2012 för ett livskraftigt Mariehamns centrum. Mariehamns stad.

Mosfellsbær. (2009). Aðalskipulag Mosfellsbæjar 2009-2024 (Endurskoðun aðalskipulagsins 2002-2024). Sveitarfélagið Mosfellsbær.

Mosfellsbær. (2013). Aðalskipulag Mosfellsbæjar 2011-2030. Stefna og skipulagsákvæði Umhverfisskýrsla. Sveitarfélagið Mosfellsbær.

Mouffe, C. (2005). On the Political. London: Routledge.

Nordic Council of Ministers. (2017). Nordic Co-operation Programme for Regional Development and Planning 2017-2020. Copenhagen: Nordic Council of Ministers. 
Nordland Fylkeskommune. (2018). Byromseminar Nordland. Available at: https://www.nfk.no/ byromseminar-nordland/om/byromseminarnordland/. Accessed on 2 November 2018.

Olsson, S. (1998). Det offentliga stadslivets förändringar. Göteborg: Centrum för byggnadskultur i västra Sverige.

Regional planbestemmelse. (2013). Regional planbestemmelse om etablering av kjøpesenter, jf. plan- og bygningsloven \& 8-5, Nordland (FOR2013-02-25-299). Available at: https://lovdata. no/dokument/OV/forskrift/2013-02-25-299. Accessed on 2 November 2018.

Regionplanekontoret. (2010). Mötesplatser i Stockholmsregionen. Stockholm: Regionplanekontoret, Stockholms läns landsting.

SCB. (2009). Tätorter 1960-2005. Sveriges officiella statistik. Statistiska meddelanden: MI 38 SM 1101.

Servillo L., Atkinson R., Smith I., Russo A., Sýkora L., Demazière C. \& Hamdouch A. (2014). TOWN, small and medium sized towns in their functional territorial context, Final Report, Espon, Luxembourg.

Servillo, L., Atkinson, R. \& Hamdouch, A. (2017). Small and medium-sized towns in Europe: Conceptual, methodological and policy issues. Tijdschrift Voor Economische En Sociale Geografie, 108 (4), 365-379.
Sieverts, T. (2003). Cities Without Cities: An Interpretation of the Zwischenstadt. London: Spon Press.

Smas, L. (2018). Urbanisation: Nordic geographies of urbanisation. In Grunfelder, J., Rispling, L., \& Norlén, G. (Eds.), State of the Nordic Region 2018 (pp. 36-46). Nordic Council of Ministers.

Soja, E. (2000). Postmetropolis: Critical Studies of Cities and Regions. Oxford: Blackwell.

Sorø Kommune. (2012). Masterplan for Sorø. Sorø Kommune.

Sorø Kommune. (2016). Sorøs grønne scene: Forprojekt for Biblioteksgården. (Document from Sorø municipality.)

Tunström, M. (2009). På spaning efter den goda staden: om konstruktioner av ideal och problem i svensk stadsbyggnadsdiskussion (Doctoral Thesis). Örebro: Örebro University.

Tunström, M. \& Bradley, K. (2015). Opposing the postpolitical Swedish urban discourse. In Metzger, J., Allmendinger, P. \& Oosterlynck, S. (Eds.) Planning Against the Political. Democratic Deficits in European Territorial Governance. London: Routledge.

Västervik Citysamverkan. (2017). Årets stadskärna 2017. Västervik kommun.

Västervik kommun. (2014). ÖP 2025: Huvuddokument. Västervik kommuns översiktsplan. Västervik kommun. 


\section{Appendix}

\begin{tabular}{|c|c|c|c|}
\hline $\begin{array}{l}\text { Interview } \\
\text { no. }\end{array}$ & Interviewee & Organization & Title/tasks \\
\hline \multirow[t]{3}{*}{1} & Annika Boman & Västervik Framåt & $\begin{array}{l}\text { Head of Platsutveckling } \\
\text { ("Place Development") }\end{array}$ \\
\hline & Sofie Hjertqvist & Västervik Municipality & Spatial Planner \\
\hline & Daniel Niklasson & Västervik Municipality & Spatial Planner \\
\hline \multirow[t]{6}{*}{2} & Peter Enberg & KlippUpp & $\begin{array}{l}\text { Private business actor and chair of } \\
\text { the steering group of City Mariehamn }\end{array}$ \\
\hline & Kai Söderlund & City of Mariehamn & $\begin{array}{l}\text { Director of Infrastructure and } \\
\text { member of the steering group of City } \\
\text { Mariehamn }\end{array}$ \\
\hline & Lars Midbjer & City of Mariehamn & $\begin{array}{l}\text { Works with cultural development and } \\
\text { member of one of the subgroups in } \\
\text { City Mariehamn }\end{array}$ \\
\hline & Sirkka Wegelius & City of Mariehamn & Municipal Spatial Planner \\
\hline & Terese Följt & City of Mariehamn & $\begin{array}{l}\text { Works with business development and } \\
\text { member of one of the subgroups in } \\
\text { City Mariehamn }\end{array}$ \\
\hline & Barbara Heinonen & City of Mariehamn & City Director \\
\hline \multirow[t]{2}{*}{3} & Lene Eriksen & Sorø Municipality & Spatial Planner \\
\hline & Vibeke Solvang & Sorø Municipality & Head of the Planning Office \\
\hline 4 & Johan Otte & Sorø Municipality & Head of City Centre Administration \\
\hline \multirow[t]{2}{*}{5} & Päivi Cainberg & Kokkola Municipality & Municipal Spatial Planner \\
\hline & Jonne Sandberg & Kokkola Municipality & Development Director \\
\hline \multirow[t]{2}{*}{6} & Tomas G. Gislason & $\begin{array}{l}\text { Mosfellsbær } \\
\text { Municipality }\end{array}$ & Environmental Director \\
\hline & Ólafur Melsteð & $\begin{array}{l}\text { Mosfellsbær } \\
\text { Municipality }\end{array}$ & Planning Officer \\
\hline 7 & Heidi Ramsvik & Region Nordland & Adviser in urban development \\
\hline 8 & $\begin{array}{l}\text { Kristoffer Larsen } \\
\text { Seivåg }\end{array}$ & Bodø Municipality & Spatial Planner \\
\hline 9 & Anne-Lise Bolland & Bodø Municipality & Head of the Planning Office \\
\hline
\end{tabular}






\section{(1I) Nordregio}

P.O. Box 1658

SE-111 86 Stockholm, Sweden

nordregio@nordregio.org

www.nordregio.org

www.norden.org 